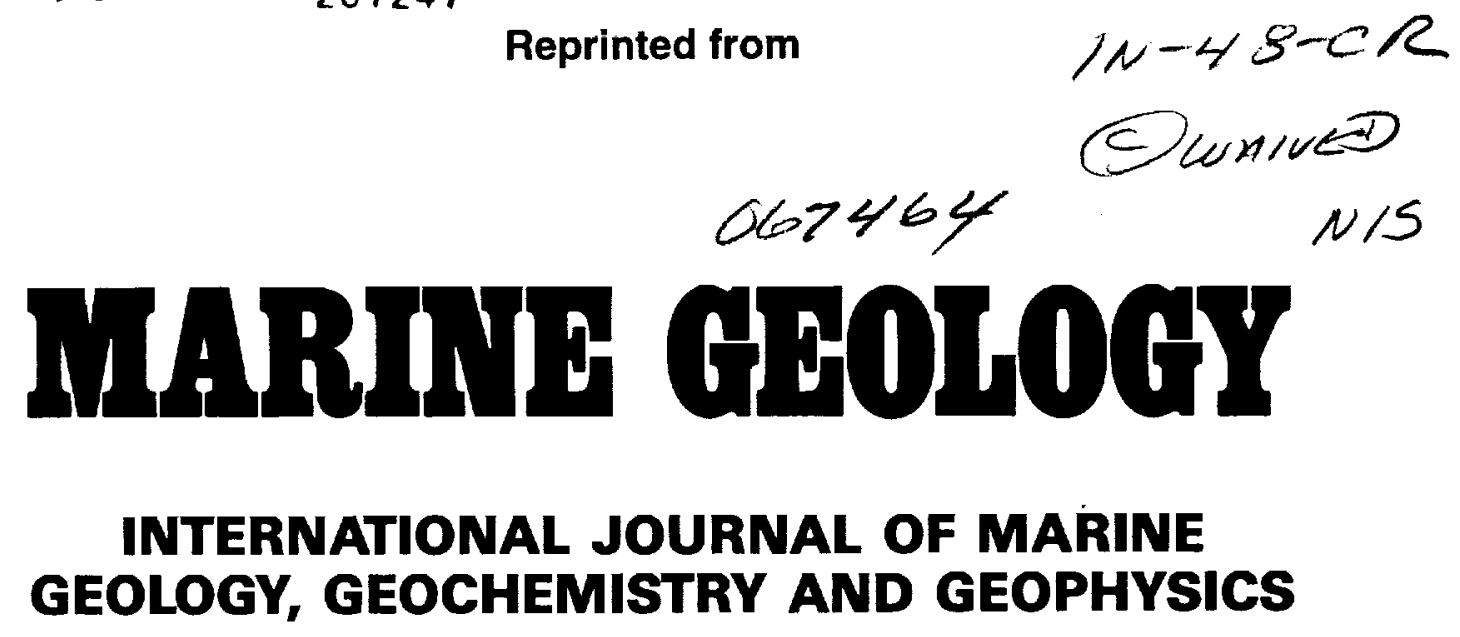

Marine Geology 138 (1997) 273-301

Characteristics of seamounts near Hawaii as viewed by GLORIA Nathan T. Bridges ${ }^{1}$

Department of Geosciences, University of Massachusetts, Amherst, MA 01003, USA

Received 8 March 1996; accepted 19 November 1996

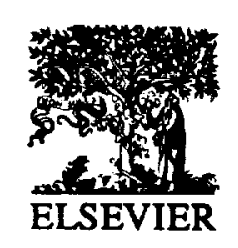




\section{Editors-in-Chief}

For Europe, Africa and the Near East:

H. Chamley, Université des Sciences et Techniques de Lille-Artois, Sédimentologie et Géochimie, B.P. 36, 59655 Villeneuve d'Ascq, France

Tel.: + 33-0320434130

For the Americas, Pacific and Far East:

M.A. Arthur, Department of Geosciences, The Pennsylvania State University, 503 Deike Building, University Park, PA 16802-2714, U.S.A.

Tel.: +1-814-865-6711; Fax: +1-814-865-3191; E-mail: arthur@geosc.psu.edu

\section{Editorial Board}

R. Batiza, Honolulu, Hawaii, USA

W. Berger, La Jolla, Calif., USA

A.H. Bouma, Baton Rouge, La., USA

A.J. Bowen, Halifax, N.S., Canada

L. Carter, Wellington, New Zealand

J.R. Curray, La Jolla, Calif., USA

P.J. Davies, Sydney, N.S.W., Australia

M.L. Delaney, Santa Cruz, Calif., USA

S.L. Eittreim, Menlo Park, Calif., USA

J.-C. Faugères, Talence, France

M.E. Field, Menlo Park, Calif., USA

G.P. Glasby, Sheffield, UK

M. Grant Gross, Baltimore, Md., USA

D.M. Hanes, Gainesville, Fla., USA

W.W. Hay, Boulder, Colo., USA

J.R. Hein, Menlo Park, Calif., USA

\section{Scope of the journal}

Marine Geology is an international medium for the publication of original studies and comprehensive reviews in the field of Marine Geology, Geochemistry and Geophysics. The editors endeavour to maintain a high scientific level and it is hoped that with its international coverage the journal will contribute to the sound development of this field.

A letter section is provided as a publication outlet for short papers which require rapid publication.

\section{Publication information}

Marine Geology (ISSN 0025-3227). For 1997 volumes 137-144 are scheduled for publication. Subscription prices are available upon request from the publisher. Subscriptions are accepted on a prepaid basis only and are entered on a calendar year basis. Issues are sent by surface mail except to the following countries where air delivery via SAL is ensured: Argentina, Australia, Brazil, Canada, Hong Kong, India, Israel, Japan, Malaysia, Mexico, New Zealand, Pakistan, PR China, Singapore, South Africa, South Korea, Taiwan, Thailand, USA. For all other countries airmail rates are available upon request. Claims for missing issues must be made within six months of our publication (mailing) date. For orders, claims, product enquiries (no manuscript enquiries) please contact the Customer Support Department at the Regional Sales Office nearest to you:

New York, Elsevier Science, P.O. Box 945, New York, NY 10159-0945, USA. Tel: (+1) 212-633-3730, [Toll Free number for North American Customers: 1-888-4ES-INFO (437-4636)l, Fax (+1) 212-633-3680, E-mail: usinfo-f@elsevier.com Amsterdam, Elsevier Science, P.O. Box 211, 1000 AE Amsterdam, The Netherlands. Tel: $(+31)$ 20-485-3757, Fax: $(+31) 20-$ 485-3432,E-mail: nlinfo-f@elsevier.nl

Tokyo, Elsevier Science, 9-15, Higashi-Azabu 1-chome, Minato-ku, Tokyo 106, Japan. Tel. (+81) 3-5561-5033, Fax: (+81) 35561-5047, E-mail: kyf04035@niftyserve.or.jp

Singapore, Elsevier Science, No. 1 Temasek Avenue, \#17-01 Millenia Tower, Singapore 039192. Tel: $(+65)$ 434-3727, Fax: (+65) 337-2230. E-mail: asiainfo@elsevier.com.sg

US mailing notice - Marine Geology (ISSN 0025-3227) is published monthly by Elsevier Science, (Molenwerf 1, Postbus 211, 1000 AE Amsterdam). Annual subscription price in the USA US\$2316 (US\$ price valid in North, Central and South America onlyl, including air speed delivery. Periodicals postage pald at Jamaica, NY 11431. USA POSTMASTERS: Send address changes to Marine Geology. Publications Expediting, Inc., 200 Meacham Avenue, Elmont, NY 11003 . Airfreight and mailing in the USA by Publications Expediting.

\section{○ 1997, ELSEVIER SCIENCE B.V., ALL RIGHTS RESERVED}

$0025-3227 / 97 / \$ 17.00$

This journal and the individual contributions contained in it are protected by the copyright of Elsevier Science B.V., and the following terms and conditions apply to their use:

Photocopving: Single photocopies of single articles may be made for personal use as allowed by national copyright laws. Permission of the publisher and payment of a fee is required for all other photocopying, including multiple or systematic copying, copying for advertising or promotional purposes, resale, and all forms of document delivery. Special rates are available for educational institutions that wish to make photocopies for non-profit educational cisssroom use. In the USA, users mav clear permissions and make payment through the Copyright Clearance Center, 222 Rosewood Drive, Danvers, MA 01923, USA. In the UK, users may clear permissions and make payment through the Copyright Licensing Agency Rapid Clearance Service (CLARCS), 90 Tottenham Court Road, London, W1P OLP.

Dertvative Works: Subscribers may reproduce tables of contents or prepare lists of articles including abstracts for internal circulation within their institutions. Permission of the publisher is required for resale or distribution outside the institution. Permission of the publisher is required for all other derivative works. inciuding compilations and translations.

Electronic Storeqe: Permission of the publisher is required to store electronically any material contained in this journal, including any article or part of an article. Contact the publisher at the address indicated.

Except as outlined above, no port of this publication may be reproduced, stored in a retrieval system or transmifted in any form or by any means, eloctronic, mechanical, photocopying, recording or otherwise, without prior written permission of the publisher.

Notice: No responsibility is assumed by the Publisher for any injury and/or domage to persons or property as a matter of products liability, negligence or otherwise, or from any use or operotion

@ The paper used in this publication meets the requirements of ANSINISO Z39.48-1992. (Permanence of Paper).

PRINTED IN THE NETHERLANDS 
Marine Geology 138 ( 1997) 273-30I

\title{
Characteristics of seamounts near Hawaii as viewed by GLORIA
}

\author{
Nathan T. Bridges ${ }^{1}$ \\ Department of Geosciences, University of Massachusetts, Amherst, MA 01003, USA
}

Received 8 March 1996; accepted 19 November 1996

\begin{abstract}
Using images and data acquired from the GLORIA sonar system, 390 seamounts within the U.S. Hawaiian Exclusive Economic Zone (HEEZ) off Hawaii have been studied. Their diameters range from 1 to $57 \mathrm{~km}$, with most less than $15 \mathrm{~km}$. Seamount abundance increases exponentially with decreasing size. The areal density of observed seamounts having diameters greater than $1 \mathrm{~km}$ is $182 / 10^{6} \mathrm{~km}^{2}$. The theoretical abundance of seamounts of all sizes normalized to a unit area is $(309 \pm 17) / 10^{6} \mathrm{~km}^{2}$, about an order of magnitude less than other surveyed areas of the Pacific. This may reflect a lower abundance of Cretaceous seamounts in this region, the covering of small seamounts by sediment, or discrepancies from the use of different data sets to derive the abundance statistics. The seamounts have morphologies ranging from steep-sided, flat-topped structures to cones to more amorphous structures; they are similar to volcanoes found elsewhere on the seafloor. A suite of secondary features associated with the seamounts includes summit craters, summit mounds, coalesced boundaries, landslides, and graben. Several seamount chains are aligned parallel to Cretaceous fracture zones, consistent with an origin close to the ancestral East Pacific Rise. Others are aligned parallel to the Necker Ridge, suggesting that they formed contemporaneously with Necker in the plate interior. This observation, together with high abundances of seamounts where other intraplate igneous processes have occurred, suggests some seamounts formed since leaving the spreading center. 1997 Elsevier Science B.V.
\end{abstract}

Keywords: Seamounts; Hawaii; GLORIA sonar; North Arch lava flow; Musicians seamounts

\section{Introduction}

The oceanic crust surrounding the Hawaiian Islands was created at the East Pacific Rise (EPR) approximately $70-130$ Myr ago (Atwater and Severinghaus, 1988). Relict tectonic features from the time of spreading include the Murray and Molokai Fracture Zones (FZ's) and the seafloor

${ }^{1}$ Present address: Jet Propulsion Laboratory, MS 230-235, 4800 Oale Grove Dr., Pasadena, CA 91109, USA. Tel.: (8I8) 393-7799; fax: (818) 393-1227;

e-mail: nathan.bridges@jpl.nasa.gov fabric perpendicular to them (Fig. 1). Other tectonic features of enigmatic origin and age include the Necker and other unnamed ridges, which trend obliquely to the seafloor fabric, indicating that they probably formed in the Pacific Plate interior at a later time. Hawaiian hotspot volcanism and the resulting islands and their products have also modified the seafloor. The region is dominated by the Hawaiian Ridge, a string of subaerial and subaqueous volcanoes erupted from the Hawaiian hotspot and carried successively northwest by movement of the Pacific Plate (Clague and Dalrymple, 1989). The load of the Ridge has 

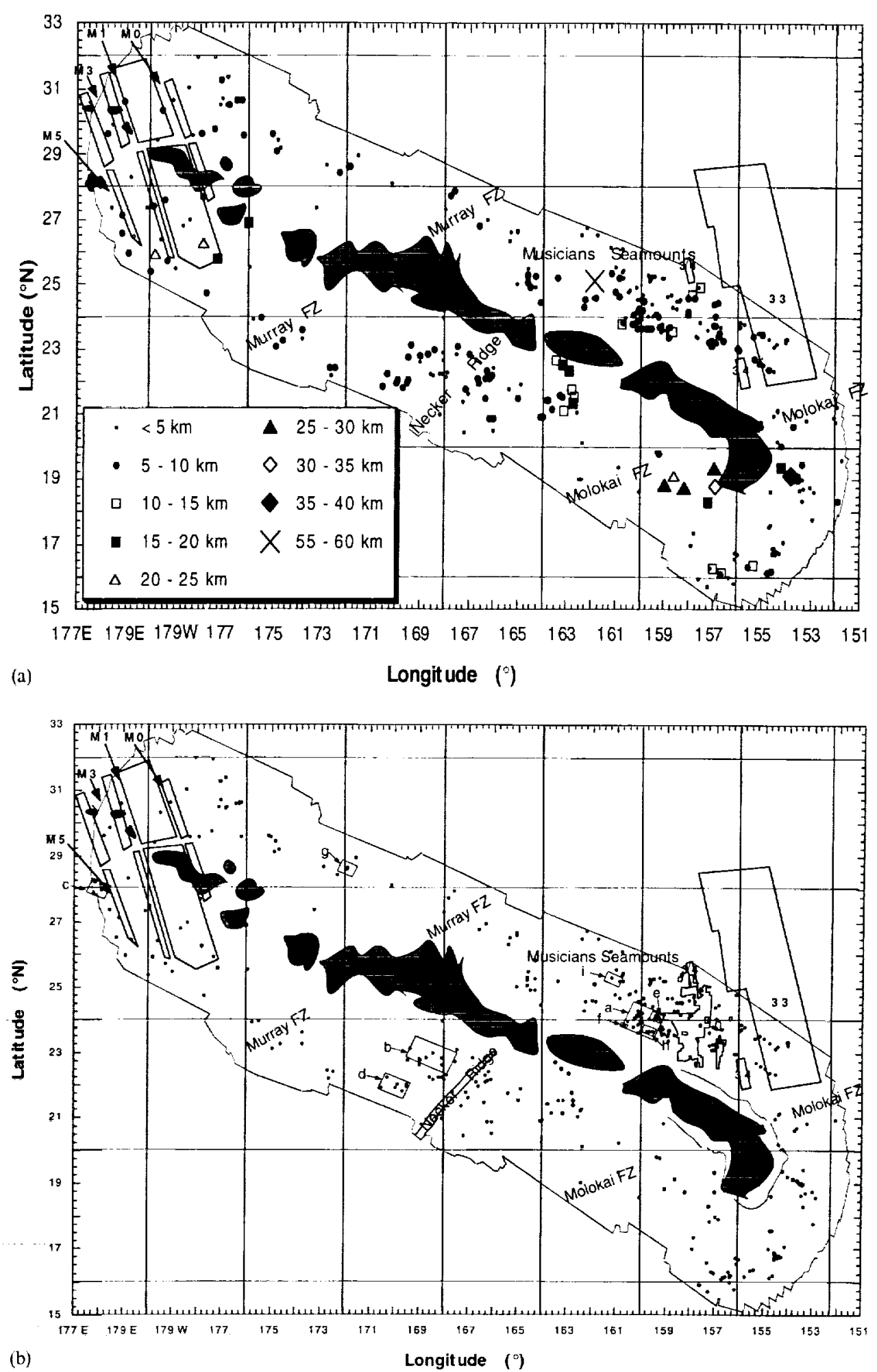
caused lithospheric flexure, producing a discontinuous moat known as the Hawaiian Deep ranging in depth from $\sim 4000$ to $\sim 5600 \mathrm{~m}$ (Fornari and Campbell, 1987; Moore, 1987; Moore et al., 1989). The Deep is filled with debris shed from the islands in the form of slump blocks and giant landslides, some of which lap onto the Deep's outer edges (Moore et al., 1989, 1994). Outside of this depression is the Hawaiian Arch, a low $(200 \mathrm{~m})$ and broad upbowing of the seafloor resulting from flexural compensation of the displaced material of the Deep (Wessel, 1993; Wessel and Keating, 1993; Moore et al., 1994). The North Arch, between the Murray and Molokai FZ's, contains a large Pliocene-Pleistocene alkalic lava flow field that is clearly visible in sonar imagery (Fig. 2a; Clague et al., 1990).

Seaward of the Deep are hundreds of seamounts, most of which have not been sampled or described. Some of these, such as Loihi southeast of the Big Island, result from volcanism associated with the Hawaiian hotspot. North of the main islands, another hotspot on young $(<15 \mathrm{Ma})$ crust near the ancestral EPR may have formed some of the Musicians seamounts (Pringle, 1993). In the present day, the most prolific site for seamount genesis in the Pacific is adjacent to the axis of the EPR (Smith and Jordan, 1988; Smith, 1991; Scheirer and Macdonald, 1995). Thus, it is reasonable to assume that many, if not most, of the seamounts seen near Hawaii also formed near the EPR and are thus nearly the same age as the underlying crust.

Due to the scarcity of samples and in situ reconnaissance studies of these and other seamounts, studies rely heavily on sonar and other remote sensing methods. This paper discusses the seamounts near Hawaii as viewed by the GLORIA sonar. The primary purposes of this work are: (1) to document the characteristics, distribution, and associations of the seamounts; (2) to compare the seamounts to others elsewhere in the Pacific; and (3) discuss what the sonar data allows us to infer about the seamounts' origin.

\section{Data and methods}

The region examined in this study, the U.S. Hawaii Exclusive Economic Zone (HEEZ) has an area of $2.38 \times 10^{6} \mathrm{~km}^{2}$ and an irregular boundary bounded by $15-33^{\circ} \mathrm{N}$ and $151^{\circ} \mathrm{W}-178^{\circ} \mathrm{E}$ (Fig. 1). Mapping of the HEEZ with the Geologic LOng Range Inclined ASDIC (GLORIA) digital side-scan sonar system took place during 1986-1991. The source and receiver of the sonar were located in a "fish" towed $\sim 200 \mathrm{~m}$ behind the ship (Gardner, 1992). Sonar pulses were emitted about every 30 s. The seafloor was imaged on either side of the ship track out to an average horizontal distance of $\sim 12.5 \mathrm{~km}$ at a spatial resolution of $\sim 50 \mathrm{~m}$. The energy or amplitude of the returned signals was stored as digital data. These were then combined into images depicting backscatter intensity as shades of gray, with white corresponding to the highest energy. High backscatter results from surfaces that are rough at the scale of the GLORIA sonar wavelength $(22-24 \mathrm{~cm}$, or 6.3 and $6.7 \mathrm{kHz}$; Geyer, 1992), such as lava, or from slopes oriented perpendicular to the beam path. In addition to the backscatter sonar information, depth at nadir was recorded with a wide-beam echo sounder at a vertical resolution of $\sim 1 \mathrm{~m}$ (W. Normark, pers. commun., 1994).

Fig. 1. Maps of the distribution of seamounts found in the GLORIA mosaic of the Hawaiian Exclusive Economic Zone (see text for identification criteria). Light, straight lines define the boundary of the map area. Dark shaded region is the approximate area of the Hawaijan Ridge. Area labeled Musicians Seamounts is southern part of area containing large seamounts of this name. Lahels for fracture zones and the Necker Ridge are along approximate trends and locations. Numbered boxes are nomal magnetic anomalies (from map of Atwater and Severinghaus, 1988): anomaly $33 \approx 7580.5 \mathrm{Ma}, 34 \approx<84.5 \mathrm{Ma}, M_{0} \approx 118 \mathrm{Ma}, M_{1} \approx 122 \mathrm{Mat}$, $M_{3} \approx\left[23.5 \cdots 125.5 \mathrm{Ma}, M_{5} \approx 127 \mathrm{Ma}\right)$.

a. Distribution map as a function of seamount diameter.

b. Distribution map showing prominent seafloor features. The Hawaiian Deep is shown in light ontline around the east end of the ridge. Rectilinear outline to north or eastern ridge is the approximate boundary of the North Arch lava flow field. Delineation of the Necker Ridge is shown as a dark outline. Lettered boxes are the boundaries of the images in Fig. 2. 


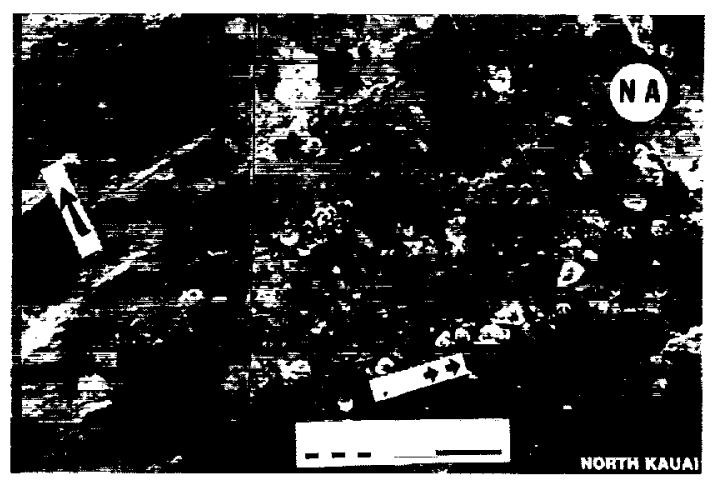

(a)
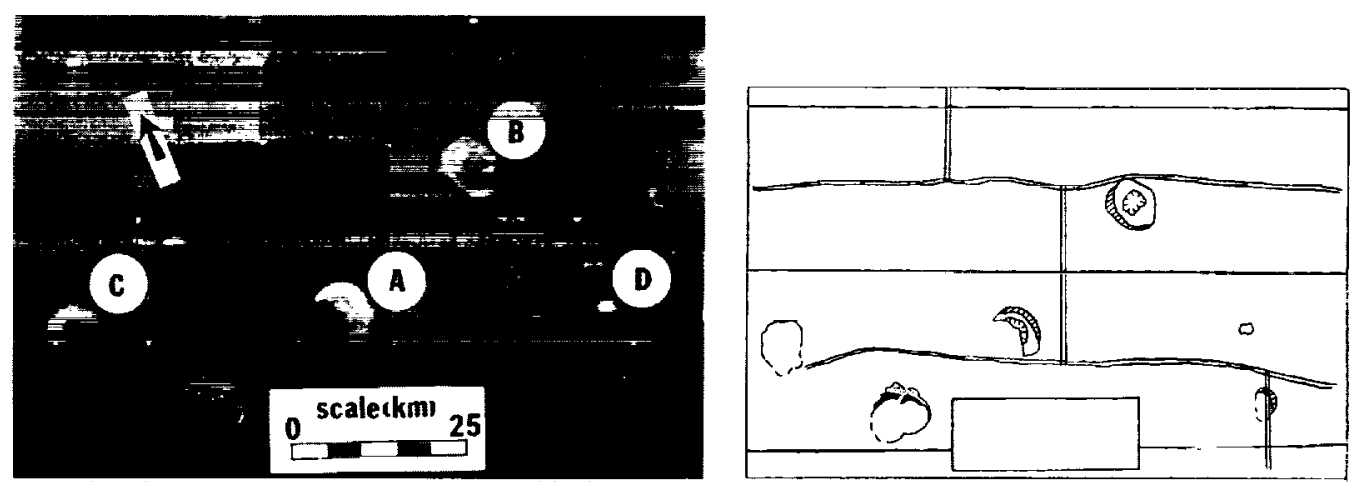

(b)

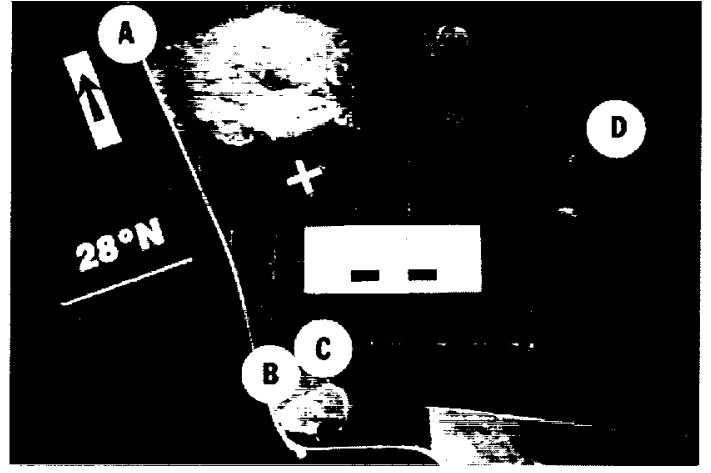

(c)

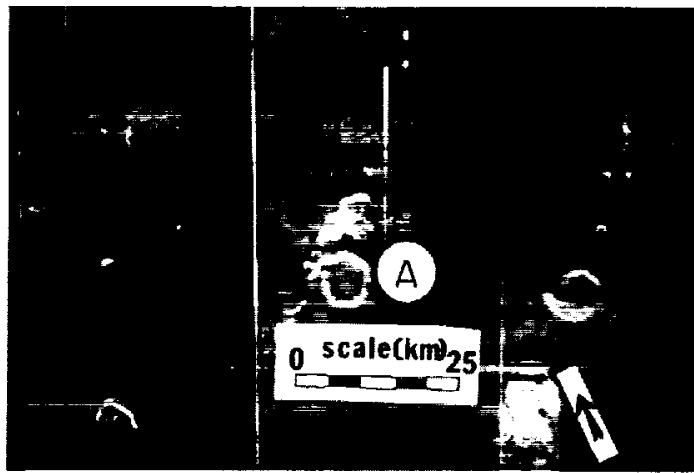

(d)

Fig. 2. GLORIA images of seamounts in the HEEZ. Brightness is proportional to sonic backscatter. Prominent horizontal lines delineate ship tracks. Black arrow in all pictures indicates north. Coordinates at the end of each caption are the approximate latitudes and longitudes at the center of the image. Outlines of the images are shown in Fig. Ib.

a. Field near the Musicians seamounts. Note the alignment of some of the constructs, direction of which are shown by arrows. The western portion of the North Arch lava flow field $(N A)$ is seen as a sonar-bright region on the right-hand side of the image $(24 \mathrm{~N}, 160 \mathrm{~W})$.

b. Left: Image of seamount field. Seamount with a truncated edge is indicated by $A$. It appears $t 0$ have a crater in its center, as does the large volcano in the upper right $(B)$. Far left volcano is representative of a heap $(C)$, and the small, bright volcano at centerright is a typical cone $(D)\left(23^{-} \mathrm{N}, 169^{-} \mathrm{W}\right)$. Right: Sketch of seamount field. Horizontal and vertical double lines are boundaries between mosaic pieces. Horizontal single lines are ship tracks. Seamount boundaries and features delineated as solid where certain, dashed where uncertain. Hatchures =crater; diagonal line fill=sonar-bright edge; dark fill=sonar shadow; stipples =landslide deposit.

c. A large irregular heap seamount (upper left, $A$ ) and two coalesced pancake volcanoes (lower left, B and C) $\left(28^{\circ} \mathrm{N}, 178^{\circ} \mathrm{E}\right) . D^{\circ}$ is the seamount shown in profile in Fig. 7.

d. A seamount fairly representative of the pancake class $(A)$. It is illuminated on both sides because mosaic frames are joined through its center $\left(22 \mathrm{~N}, 170^{-} \mathrm{W}\right)$. 


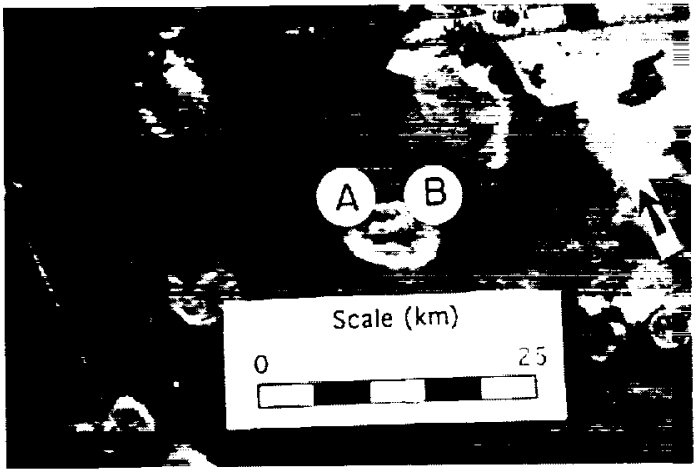

(c)

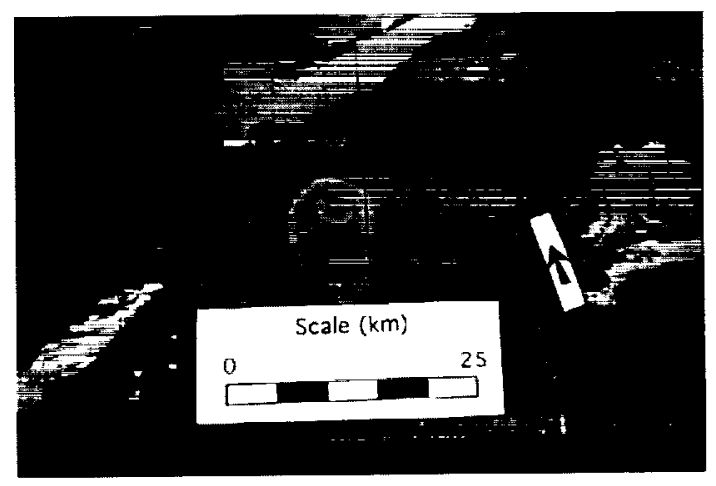

(f)

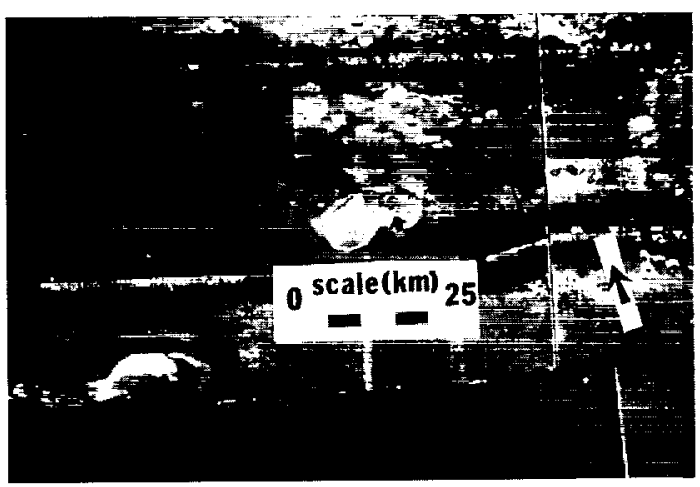

(g)
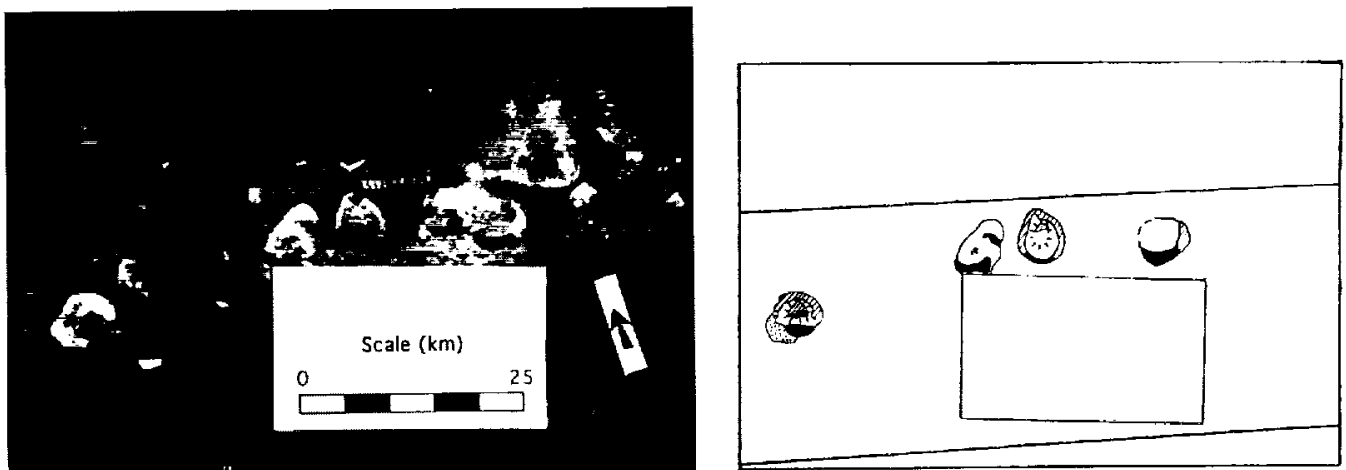

(h)

Fig. 2.e. Seamount with two large craters $(A$ and $B)$. Bright terrain in upper right is a portion of the North Areh lava flow field $\left(24^{\mathrm{N}} \mathrm{N}, 159.5 \mathrm{~W}\right)$.

f. Elongated seamount with a large crater $\left(24^{n} \mathrm{~N}, 161^{\mathrm{h}} \mathrm{W}\right)$

g. Coalesced seamounts. Note mound atop the right volcano, indicated by an $\operatorname{arrow}\left(28.5^{\circ} \mathrm{N}, 172 \mathrm{~W}\right)$.

h. Left: Image of seamount field. Mounds on seamount summits are shown by arrows. Bright material on SW flank of seamount labeled $L$ may be a landslide deposit $(23.6 \mathrm{~N}, 159.8 \mathrm{~W})$. Right: Sketch of seamount field. Nearly horizontal lines cutting across image are ship tracks. Seamount boundaries and features delineated as solid where certain, dashed where uncertain. Hatchures = mound; diagonal line fill = sonar-bright edge; $d a r k$ fill = sonar shadow; stipples $=$ landslide deposit 


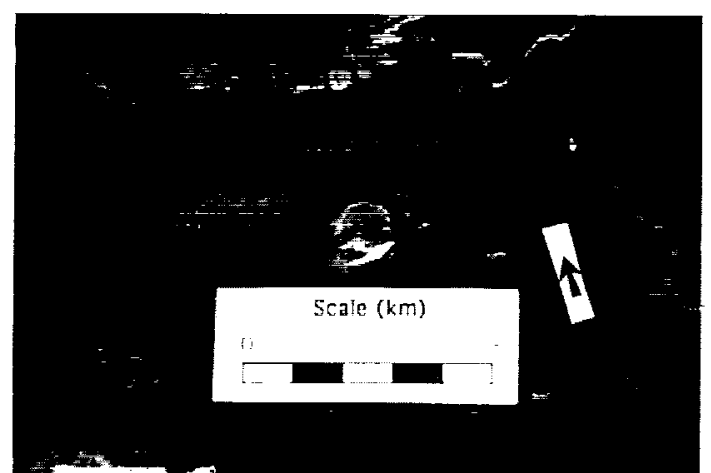

(i)

Fig. 2.i. Seamount disrupted by a graben $(25.3 \mathrm{~N}, 161.2 \mathrm{~W})$.

In this study, the GLORIA sonar image mosaic of the Hawail EEZ was used to identify and visually inspect seamounts distal from the Hawailan Ridge. The mosaic consists of individual side-scan sonar imagery strips pasted together parallel to the ship tracks (Fig. 2b) and provides a synoptic view of the HEEZ. The distinguishing characteristics used to identify volcanic constructs as "seamounts" were a circular to semi-circular outline and a sonar-brightness different than the surrounding seafloor. This term is not restricted to a specific size range or mode of origin.

To subdivide the seamount population, a qualitative classification was applied to each volcano. Constructs with a generally equant shape and a fairly uniform, bright appearance on the sonarfacing side were classified as "cones" (Fig. 2b). These were interpreted as more or less conical structures lacking wide, flat tops. At the other end of the scale, seamounts with a homogeneous sonargray interior commonly surrounded by a welldefined bright annulus on the sonar-facing edge were interpreted as flat-topped, steep-sided "pancake" constructs (Fig. $2 \mathrm{c}$ and d). The remaining volcanoes commonly were more amorphous and generally lacked a distinct contrast between their edge and interior. They were interpreted as irregular masses of lava and sediment and classified as "heaps" ( Fig. 2b). In a few cases amorphous heaps were found to form elongated ridges and were designated "ridge mounds". Rare, generally large seamounts with prominent radiating, sonar-bright spines probably representing flank rift zones (Vogt and Smoot, 1984) were classified as "stars". The classification is not perfect. For one, sonar brightness is a function not only of topography, but also of the cm-scale roughness of the surface and nearsurface materials (Barone and Ryan, 1990). In some cases it was difficult to determine whether brightness variations were caused only by topography or were also influenced by the distribution of sonar-bright lava and sonar-dark sediment. Indeed, as will be discussed in greater detail later, the limited bathymetry available for pancake seamounts shows that they are not as steep-sided or flat-topped as they appear to be in sidescan imagery. Second, regardless of the brightness problem, simply classifying the seamounts was often difficult and somewhat subjective. The seamounts have a range of morphologies that do not necessarily represent distinct end-members. The reader is urged to consult other seamount studies that employ side-scan sonar for further discussion of these and other problems (e.g., Searle, 1983; Fornari et al., 1987a; Barone and Ryan, 1990; Scheirer and Macdonald, 1995).

The approximate positions of the seamounts were found from fiducial marks on the mosaic edges and by comparison to an unpublished accompanying map (prepared by R. Holcomb). Maximum and minimum diameter were compiled for each seamount. Special geomorphological features associated with the seamounts, such as the presence of summit craters, landslides, and erosional features, also were compiled. These data are listed in Appendix A.

An attempt was made to measure seamount heights from the bathymetric maps of Chase et al. (1992). However, because the maps were produced by interpolation of scattered bathymetric measurements, they generally lacked the spatial resolution to identify most scamounts. In addition, no maps were available for the western half of the HEEZ at the time of this study. HEEZ data from Seabeam, a wide-beam echo sounder superior to GLORIA in characterizing seamount shapes, cover few of the regions where scamounts are found in this study. Thus, except for two GLORIA bathymetry measurements discussed later, height was not investigated. 


\section{Observations and results}

\subsection{Quantitative characteristics}

Over the area of the Hawaii EEZ, 390 seamounts greater than $1 \mathrm{~km}$ in diameter were found (Figs. 1 and 2; Appendix A). This gives an areal density of 164 seamounts per $10^{6} \mathrm{~km}^{2}$ for this size range. Factoring out the $\sim 10 \%$ of the region occupied by the Hawaiian Ridge, the abundance is 182 volcanoes $/ 10^{6} \mathrm{~km}^{2}$.

The diameters of the HEEZ seamounts range from $\sim 1$ to $57 \mathrm{~km}$. Only 18 seamounts $(5 \%)$ are larger than $15 \mathrm{~km}$. Plotting relative abundance vs. diameter of seamounts $\leq 16 \mathrm{~km}$ in diameter in $2-\mathrm{km}$ bins shows that the modal diameter group is between 2 and $4 \mathrm{~km}$ (Fig. 3). The number of seamounts increases fairly steadily down to diameters of $2 \mathrm{~km}$, after which there is a large drop.
This decrease is probably due to the difficulty in identifying small seamounts with the available data.

In order to compare the size distribution of the HEEZ seamounts to other Pacific data sets, the cumulative seamount abundance as a function of diameter was plotted in Fig. 4 and fit to the exponential equation:

$v(D)=v_{0} \exp (-\alpha D)$

where $y(D)$ is the cumulative abundance of seamounts of diameter $d \geq D$ per unit area; $v_{0}$ the total number of seamounts of all sizes greater than zero per unit area; and $\alpha^{-1}$ the characteristic diameter (Jordan et al., 1983; Smith and Jordan, 1988). $x$ determines the slope of the abundance--diameter exponential line fit, with greater characteristic diameters giving shallower slopes. $\alpha$ and $v_{0}$ were computed using the methods of Jordan et al.

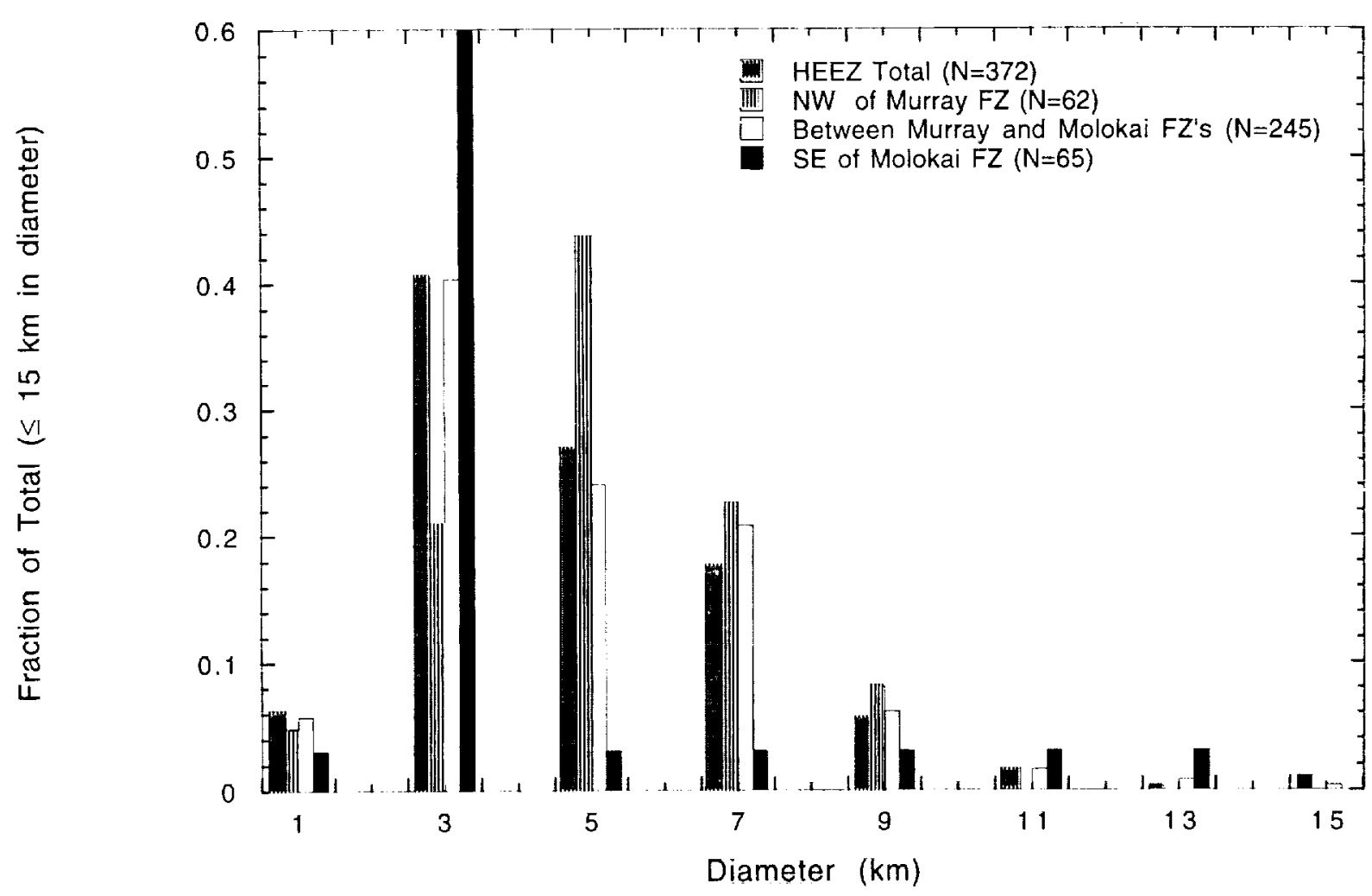

Fig. 3. Diameter vs. fractional abundance, normalized to the number of seamounts in each of the four regions. The bins are $2 \mathrm{~km}$ wide, centered on the value listed, inclusive at their lower boundary and exclusive at their upper. Seamounts with diameters greater than $16 \mathrm{~km}$ are not included. 


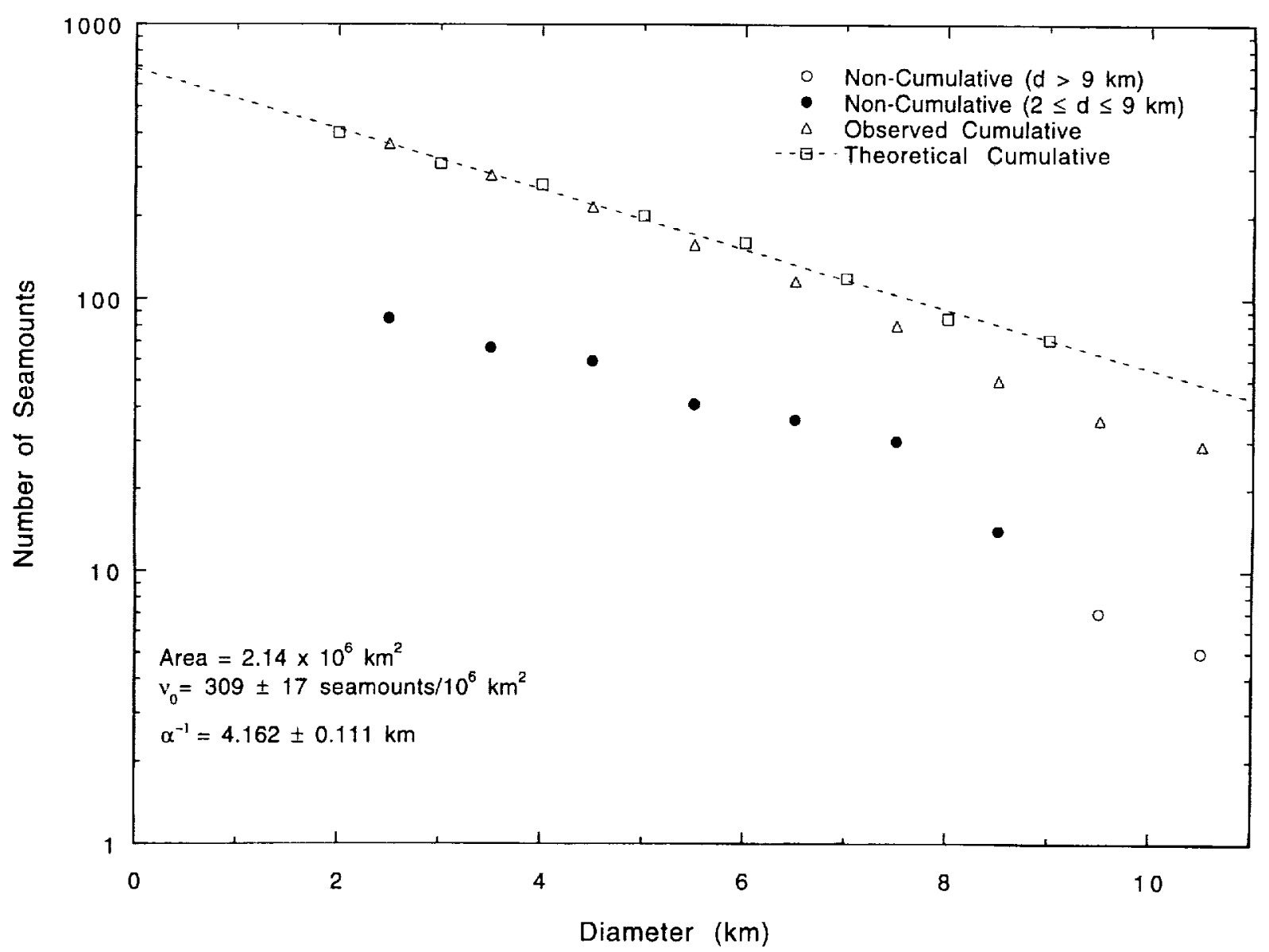

Fig. 4. Abundance and cumulative abundance vs. diameter in $1-\mathrm{km}$ bins for the whole HEEZ. Non-cumulative diameter bins are $1 \mathrm{~km}$ wide, centered on the value listed, inclusive at their lower boundary and exclusive at their upper. Open circles were eliminated in the statistical analysis to compute $v_{0}$ and $x^{-1}$. The theoretical cumulative counts are not actual values, but assume a statistically derived number of seamounts larger than the maximum size found, as explained in Smith and Jordan (1988).

(1983) and Smith and Jordan (1988). $\alpha^{-1}$ and $v_{0}$ for the whole HEEZ, minus the area of the Hawaiian Ridge, are $4.16 \pm 0.11 \mathrm{~km}$ and $309 \pm 17$ seamounts $/ 10^{6} \mathrm{~km}^{2}$, respectively (Fig. 4).

\subsection{Morphology}

The distribution of the seamounts as a function of morphologic class is shown in Fig. 5. Out of the volcano population, $127(33 \%)$ were classified as heaps (Fig. 2c), 38 (10\%) were categorized as cones (Fig. 2b), 6 (2\%) were labeled stars, and 3 (1\%) were called ridge mounds. The remaining 216 (55\%) were classified as pancakes (Fig. $2 \mathrm{c}$ and d).
The seamounts are generally bilaterally symmetric. They commonly exhibit distinct morphologic features and the compilation reveals the most prevalent forms (Fig. 6). Sixty-two volcanoes, or $16 \%$ of the data set, have one or more central craters (Figs. 2e-f). Forty-three (11\%) are surmounted by one or more mounds (Fig. $2 \mathrm{~g}$ and h). Seventeen (4\%) consist of an apparent grouping of coalesced volcanoes that together make up a larger structure (Figs. 2b and g). Nine (2\%) have edges that are truncated (Fig. 2b). Nine (2\%) have landslides on their flanks (Fig. 2h). Three (1\%) are cut by graben (Fig. 2i), with strikes of ENE-WSW (the one pictured in Fig. 2i), NE-SW, 


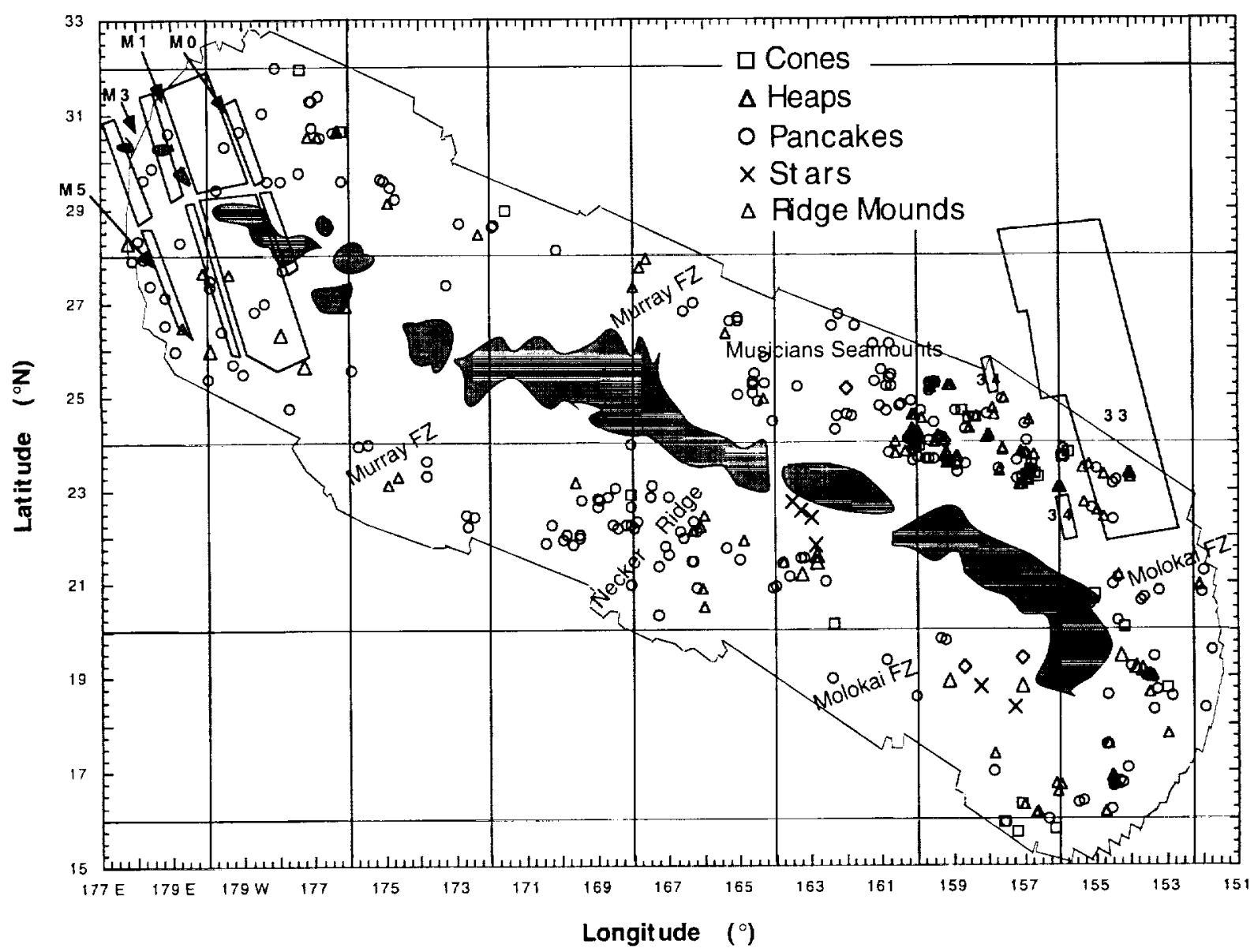

Fig. 5. Same as Fig. 1, but showing scamounts by class.

and NW SE. The remaining volcanoes $(260 ; 67 \%)$ lack these special features.

To gain some insight into the cross-sectional shapes of the HEEZ seamounts, wide-beam echosounding measurements were retrieved from raw bathymetric records. Depth measurements were restricted to lines directly below the ship, so that only two profiles crossing seamounts were obtained. One profile, at $27.4 \mathrm{~N}, 178.4 \mathrm{E}$, is shown in Fig. 7. The seamount as seen on the GLORIA mosaic is shown in Fig. 2c. Maximum height above the seafloor along the cross-section is $42 \mathrm{~m}$ and the width is $4.4 \mathrm{~km}$. This gives a crosssection aspect ratio (height/diameter) of 0.01 . In contrast, most Pacific seamounts have aspect ratios near 0.1 , although some are as low as 0.03 (Smith, 1988). This profile may be through the center of an anomalously low aspect ratio seamount. More likely, the seamount probably has an aspect ratio somewhat larger than 0.01 , but the profile is on the flank of the structure. Another profile, near $21.5 \mathrm{~N}, 163.2 \mathrm{~W}$ (Fig. 8) has a maximum height beneath the track of $305 \mathrm{~m}$. It is $8.9 \mathrm{~km}$ wide along track, giving a cross-section aspect ratio of 0.03 . Its steepest slopes, enhanced in appearance by the vertical exaggeration, are at the base. Although both of these seamounts look like pancakes in the GLORIA mosaic, one is clearly much flatter than the other. This is a reflection of the difficulty of visually distinguishing the morphology of anything 


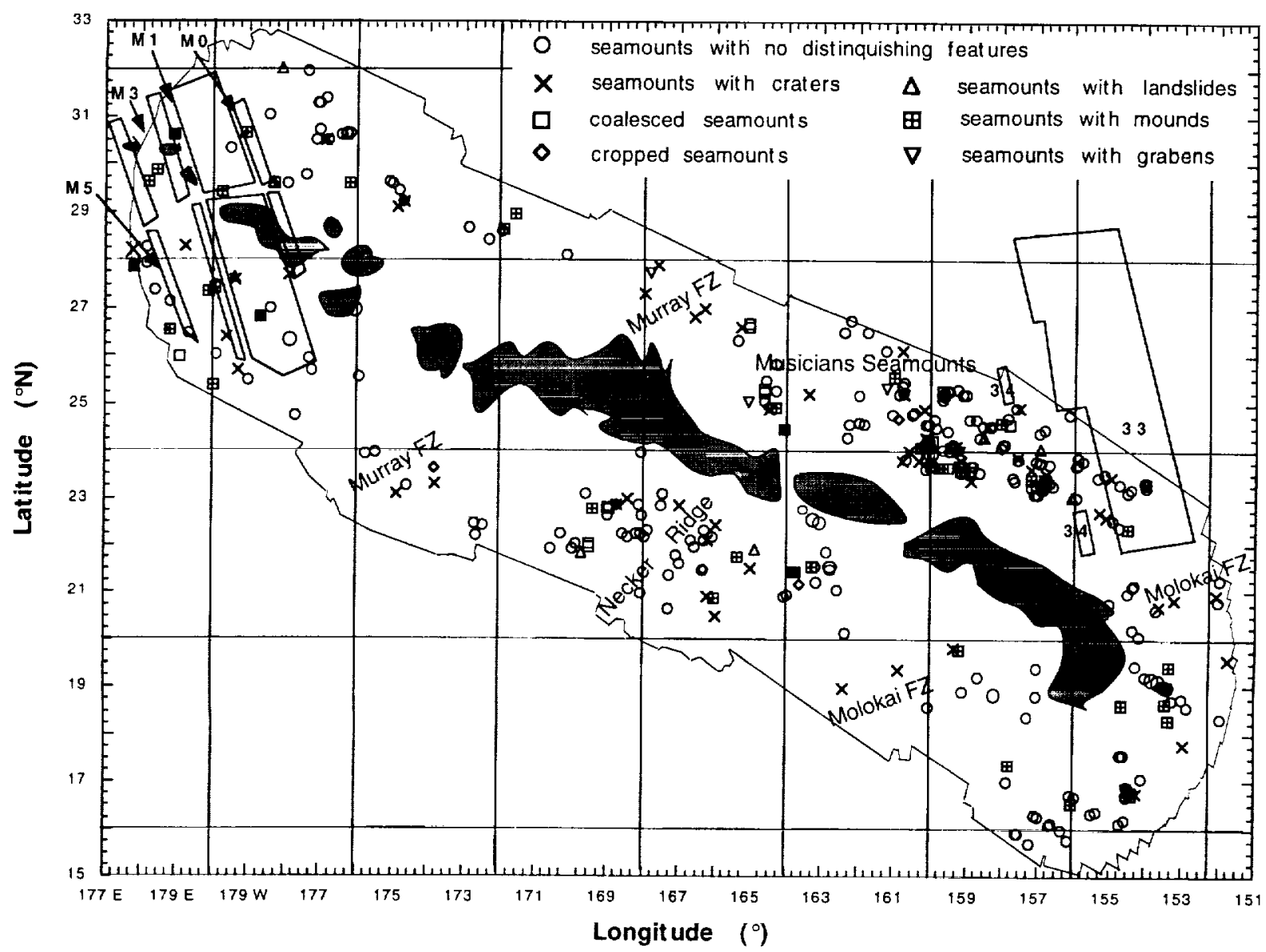

Fig. 6. Same as Fig. I, but showing seamounts by type of ancillary feature. Symbols are superimposed where more than one ancillary feature is present.

near nadir. The problems with nadir viewing also make it difficult to assess the position of the bathymetric track atop the seamount.

\subsection{Regional variations}

Regional variations were examined to see if location or tectonic setting affected the areal density, size distribution, and characteristics of the HEEZ seamounts. In general, seamount distribution is clumpy, with only a few isolated volcanoes (Fig. 1). In some cases, the seamounts are densely clustered and two or more are merged, forming a single "coalesced" edifice (see above). The seamounts are concentrated mostly north of the islands. Within this region, some seamounts are aligned along the same trend as the fracture zones (Fig. 2a). In the south-central region, many seamounts are aligned along a trend parallel to the Necker Ridge (Fig. 1). Fewer seamounts are located in the west-central and southeast-central regions of the map area. Within $1^{3} \times 1^{\text {1 }}$ quadrangles away from the Hawaiian Arch, the minimum number of seamounts is zero, and the maximum number is $18\left(24-25^{\circ} \mathrm{N}, 160-161^{\circ} \mathrm{W}\right.$, within the southern Musicians seamounts and between the Murray and Molokai FZ's). No geographic clustering of volcanoes by class (Fig. 5) or distinguishing feature (Fig. 6) is apparent. 


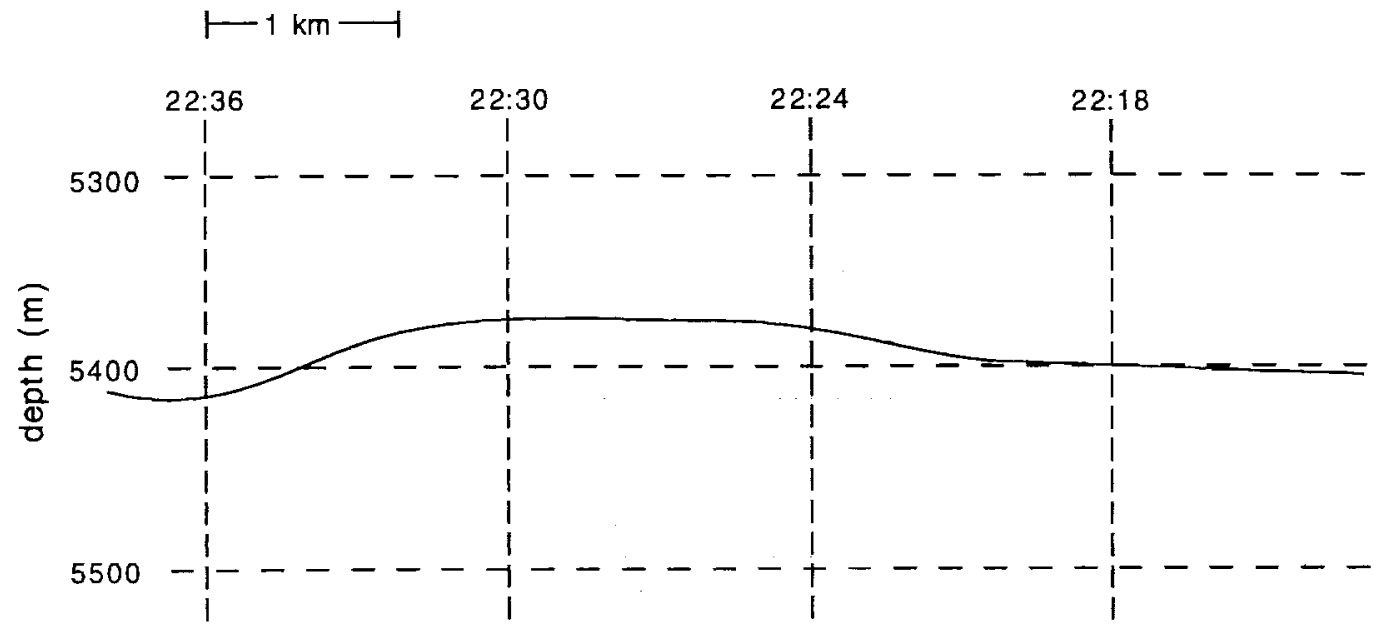

Fig. 7. Profile of a seamount at $27.4 \mathrm{~N}, 178.4 \mathrm{E}$ from the nadir-viewing wide-beam GLORIA echosounder. Depth in meters is shown on the left side. The top numbers are the time at which the ship was over this part of the seafloor. With a ship speed of $8 \mathrm{knots}$ (W. Normark, pers. commun., 1994), each 6-min block on the diagram is cquivalent to $\sim 1.5 \mathrm{~km}$. The vertical exaggeration is slightly greater than $9 \times$. This seamount is labeled $D$ in Fig. 2 c.

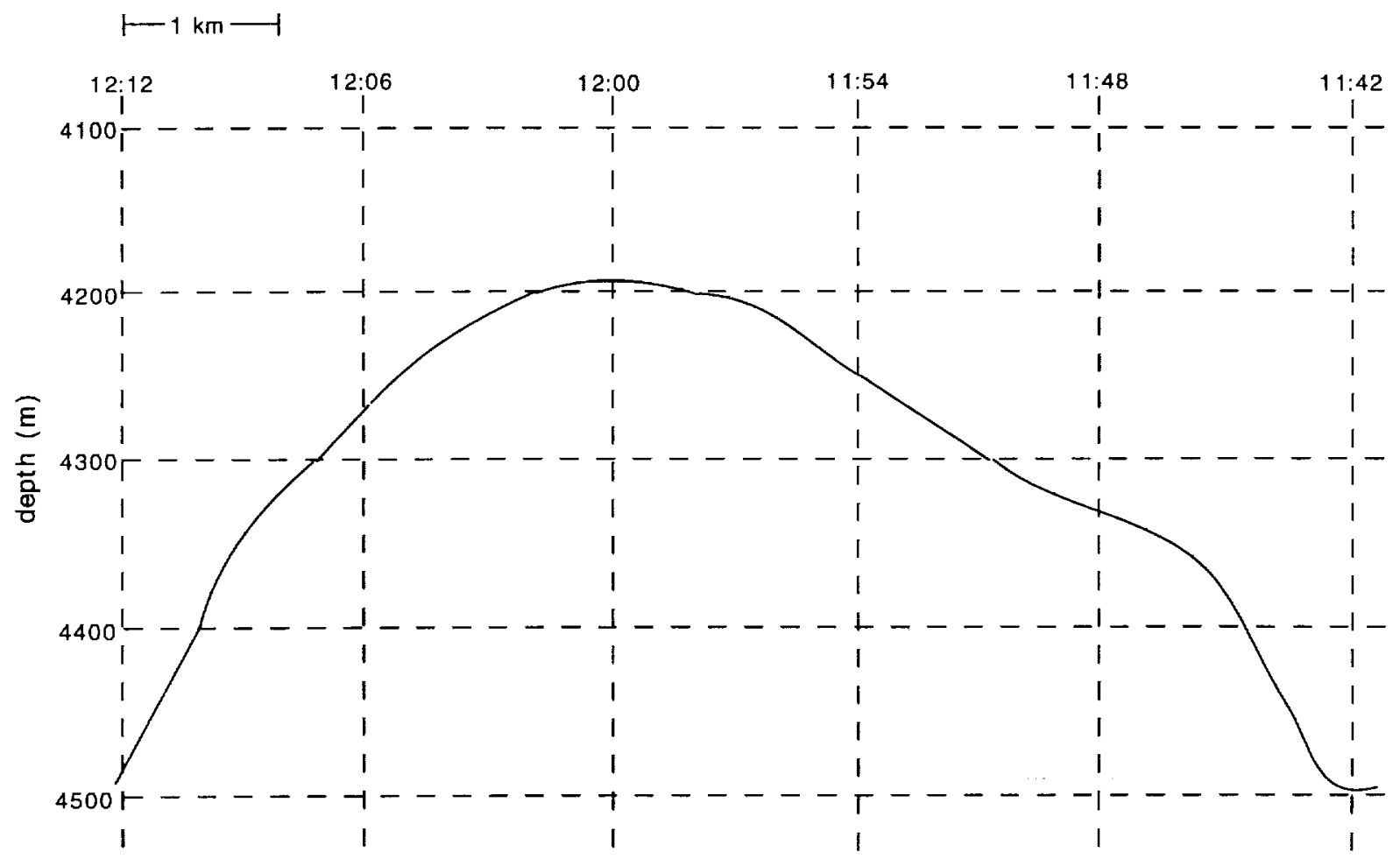

Fig. 8. Profile of a submarine volcano at $21.5 \mathrm{~N}, 163.2 \mathrm{~W}$. A.xes same as in Fig. 7. The vertical exaggeration is slightly greater than $10 \times$. 
The Murray and Molokai FZ's trend roughly perpendicular to the strike of the Hawaiian Ridge and divide the HEEZ into three tectonic regions. In the area northwest of the Murray FZ, which includes $\sim 40 \%$ of the HEEZ, 67 seamounts larger than $1 \mathrm{~km}$ were found, for a density of 78 seamounts $10^{6} \mathrm{~km}^{2}$ (area excludes the Hawaiian Ridge). The theoretical areal density of seamounts of all sizes $\left(v_{0}\right)$ and characteristic diameter $\left(\alpha^{-1}\right)$ are $(212 \pm 28) / 10^{6} \mathrm{~km}^{2}$ and $17.7 \pm 0.4 \mathrm{~km}$, respectively (Table 1). The $40 \%$ of the HEEZ between the Murray and Molokai FZ's has 250 seamounts larger than $1 \mathrm{~km}\left(292 / 10^{6} \mathrm{~km}^{2}\right) . v_{0}$ and $x^{-1}$ are $503 \pm 34$ seamounts $/ 10^{6} \mathrm{~km}^{2}$ and $4.48 \pm 0.13 \mathrm{~km}$, respectively (Table 1 ). This region contains the Pliocene-Pleistocene North Arch lava flows and associated vents (Clague et al., 1990). The remaining $20 \%$ of the HEEZ southeast of the Molokai FZ has 73 observed seamounts larger than $1 \mathrm{~km}$ $\left(171 / 10^{6} \mathrm{~km}^{2}\right) . v_{0}$ is $187 \pm 26$ seamounts/ $10^{6} \mathrm{~km}^{2}$ and $\alpha^{-1}$ is $4.88 \pm 0.32 \mathrm{~km}$ (Table 1). A correlation of magnetic anomalies adjacent to the Cretaceous quiet zone (Atwater and Severinghaus, 1988) indicates that the seafloor between the Murray and Molokai FZ's is $\sim 17 \mathrm{Myr}$ younger than the adjacent tectonic regions, so that the youngest crust in this region of the Pacific has the most seamounts.

The seamounts SE of the Molokai FZ and between the two fracture zones have modal diameters of 2-4 km like that found in the overall HEEZ (Fig. 3). Northwest of Murray the modal diameter is larger, at $46 \mathrm{~km}$. The seamounts southeast of the Molokai FZ in the $2-4-\mathrm{km}$ bin represent $60 \%$ of the population of this region, the largest fraction occupied by any $2-\mathrm{km}$ bin for the three tectonic regions and the overall HEEZ.

No prominent trends of seamount diameter parallel to the strike of the Hawaiian Ridge are apparent (Fig. 9a). Seamount morphologic classes show no trends or clumping in this direction nor do they favor any particular tectonic zone. Plotting diameter vs. distance perpendicular to the strike of the Murray and Molokai FZ's shows that seamounts near the fracture zones have, on average, smaller diameters and are fewer in number than more distal ones (Fig. 9b and c, respectively). The distribution of morphologic classes relative to the fracture zones is random. Note that the irregular boundary of the map area somewhat inhibits a completely rigorous statistical analysis of seamount distribution.

Table 1

Pacific seamount areal density $\left(v_{0}\right)$ and characteristic diameter $\left(x^{-1}\right)$

\begin{tabular}{|c|c|c|c|c|c|}
\hline Region & $v_{0}$ & $v_{2}$ & $v_{b}$ & $\begin{array}{l}x^{-1} \\
(\mathrm{~km})\end{array}$ & Source \\
\hline HEEZ & $309 \pm 17(182)$ & $191 \pm 11(171)$ & $73 \pm 4(54)$ & $4.16 \pm 0.11$ & this study \\
\hline $\begin{array}{l}\text { NW of Murray fracture zone } \\
\text { in HEEZ }\end{array}$ & $212 \pm 28(78)$ & $189 \pm 25(75)$ & $151 \pm 20(28)$ & $17.68 \pm 0.36$ & this study \\
\hline $\begin{array}{l}\text { Between Molokai and Murray } \\
\text { fracture zones in HEEZ }\end{array}$ & $503 \pm 34(292)$ & $322 \pm 22(276)$ & $132 \pm 9(91)$ & $4.48 \pm 0.13$ & this study \\
\hline $\begin{array}{l}\text { SE of Molokai fracture zone } \\
\text { in HEEZ }\end{array}$ & $187 \pm 26(171)$ & $124 \pm 17(156)$ & $55 \pm 8(33)$ & $4.88 \pm 0.32$ & this study \\
\hline Pacific (average of 8 areas) & $5440 \pm 650$ & & & $3.17 \pm 0.4$ & $\begin{array}{l}\text { Jordan et al. (1983); } \\
\text { Smith and Jordan (1988) }\end{array}$ \\
\hline $\begin{array}{l}\text { Between Clarion and Murray } \\
\text { fracture zones, East Pacific ("Area l") }\end{array}$ & $6750 \pm 2050$ & & & $2.57 \pm 0.38$ & Smith and Jordan (1988) \\
\hline $\begin{array}{l}\text { Between Murray and Mendocino } \\
\text { fracture zones, East Pacific (“Area 2") }\end{array}$ & $1660 \pm 650$ & & & $3.08 \pm 0.67$ & Smith and Jordan (1988) \\
\hline
\end{tabular}

Values of $y$ for an area of $10^{6} \mathrm{~km}^{2}$; subscript of $\mathrm{y}$ is the seamount diameter $(\mathrm{km})$ equal to and above which theoretical cumulative seamount abundances were computed; values in parentheses are actual abundances per $10^{6} \mathrm{~km}^{2} . x^{-1}$ for areas "I" and " 2 " converted from characteristic height by assuming a seamount height to diameter (aspect) ratio of 0.1 . 

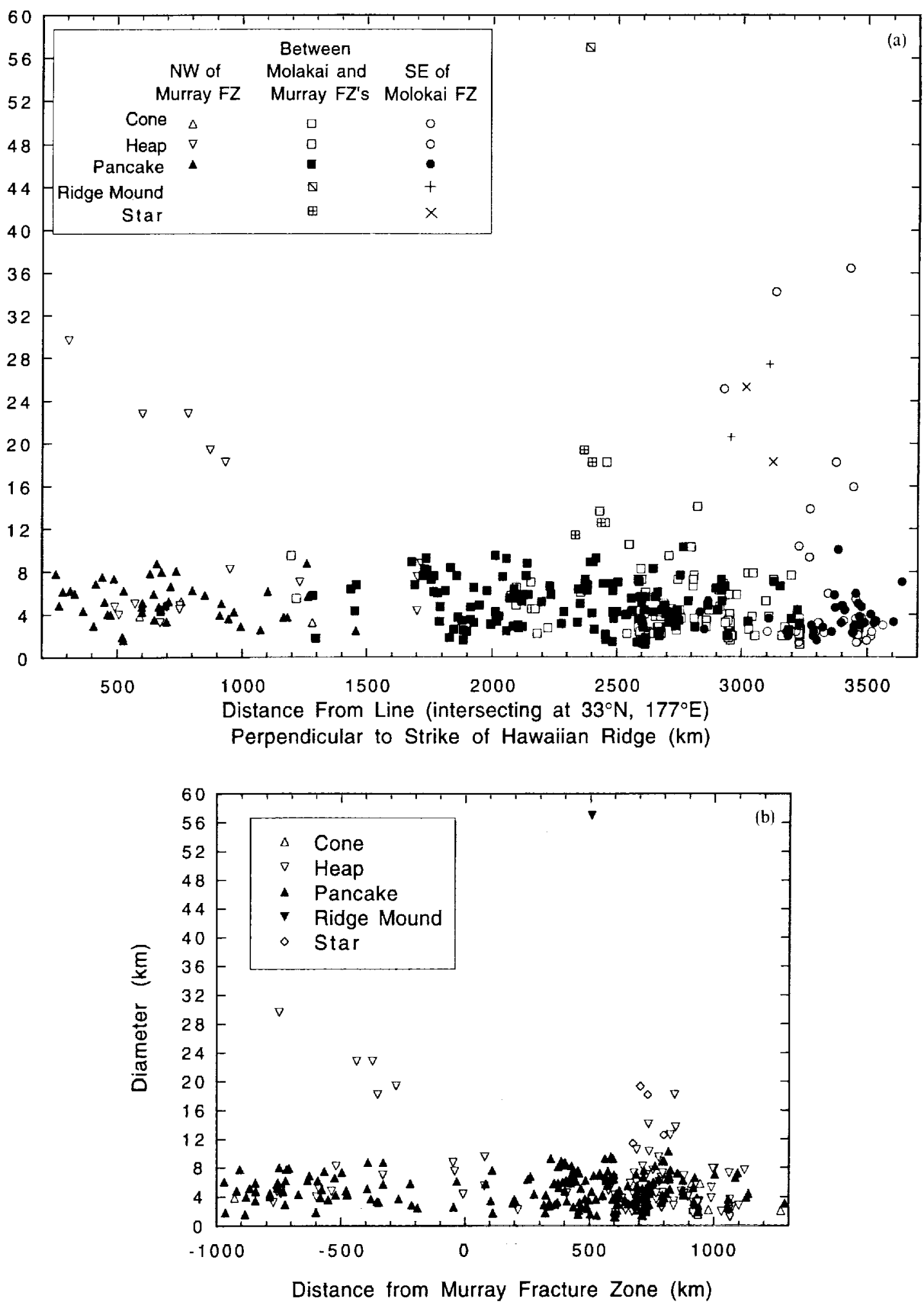


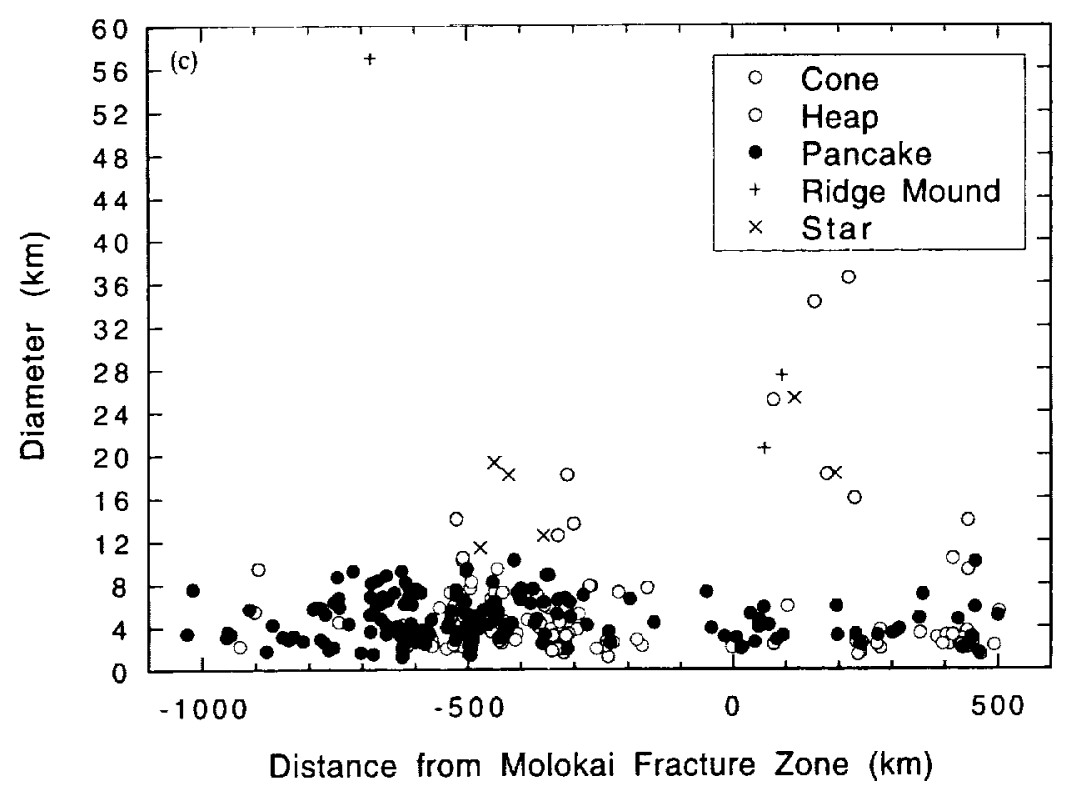

Fig. 9. a. Seamount diameter vs. distance $(\mathrm{km})$ from a line perpendicular to the strike of the Hawaiian Ridge that intersects $33 \mathrm{~N}$, $177^{\circ} \mathrm{E}$ (near the northwest extent of the HEEZ).

b. Seamount diameter vs. distance $(\mathrm{km})$ from the strike of the Murray Fracture Zone. Negative values are west of the fracture zone, positive values are east. The eastern end of the plot is near the Molokai Fracture Zone.

c. Seamount diameter vs. distance $(\mathrm{km})$ from the strike of the Molokai Fracture Zone. Negative values are west of the fracture zone, positive values are east. The western end of the plot is near the Murray Fracture Zone.

\section{Comparisons to other Pacific seamounts}

\subsection{Abundances and distributions}

The theoretical concentration of seamounts from the exponential model $\left(v_{0}\right)$ of $309 \pm 17$ per $10^{6} \mathrm{~km}^{2}$ in the HEEZ is much less than that determined in most other Pacific regions using modern high-resolution sonar surveys (Table 2) (Smith, 1991). Smith and Jordan (1988), in their study of seamount statistics in eight areas of the Pacific, estimated an average $v_{0}$ of $5440 \pm 650$ seamounts $/ 10^{6} \mathrm{~km}^{2}$. This was based on $11,506 \mathrm{~km}$ of Seabeam tracks in the eastern Pacific in which 186 seamounts having heights from 100 to $1100 \mathrm{~m}$ were found. None of the areas in their study included the HEEZ. The two closest regions are their areas 1 and 2 . Area 1 is between the Clarion and Murray FZ's and extends from the eastern HEEZ boundary to near the southern Californian and northern Mexican coasts. Area 2 is between the Murray and Mendocino FZ's and extends from north of the HEEZ to near the northern Californian coast. The theoretical areal densities in areas 1 and 2 are $6750 \pm 2050$ and $1660 \pm 650$ seamounts $10^{6} \mathrm{~km}^{2}$, respectively. The lesser theoretical abundance of seamounts in area 2 relative to area 1 (i.e., north and south of the Murray FZ, respectively) is consistent with the theoretical areal density contrasts found here $(212 \pm 28$ vs. $503 \pm 34)$ (Table 1). Thus, although the absolute abundances of seamounts differ between this study and that of Smith and Jordan, the decrease in predicted abundances going north across the Murray FZ agree.

The alignment of some HEEZ seamounts along the trends of fracture zones is analogous to seamount chains aligned parallel to the spreading direction and transform faults adjacent to the modern EPR (Batiza and Vanko, 1983; Fornari et al., 1984; Macdonald et al., 1984; Lonsdale, 1985; Macdonald, 1989; Scheirer and Macdonald, 1995). It is therefore likely that these seamounts are about the same age as the underlying crust. For EPR-derived seamounts, the abundance con- 


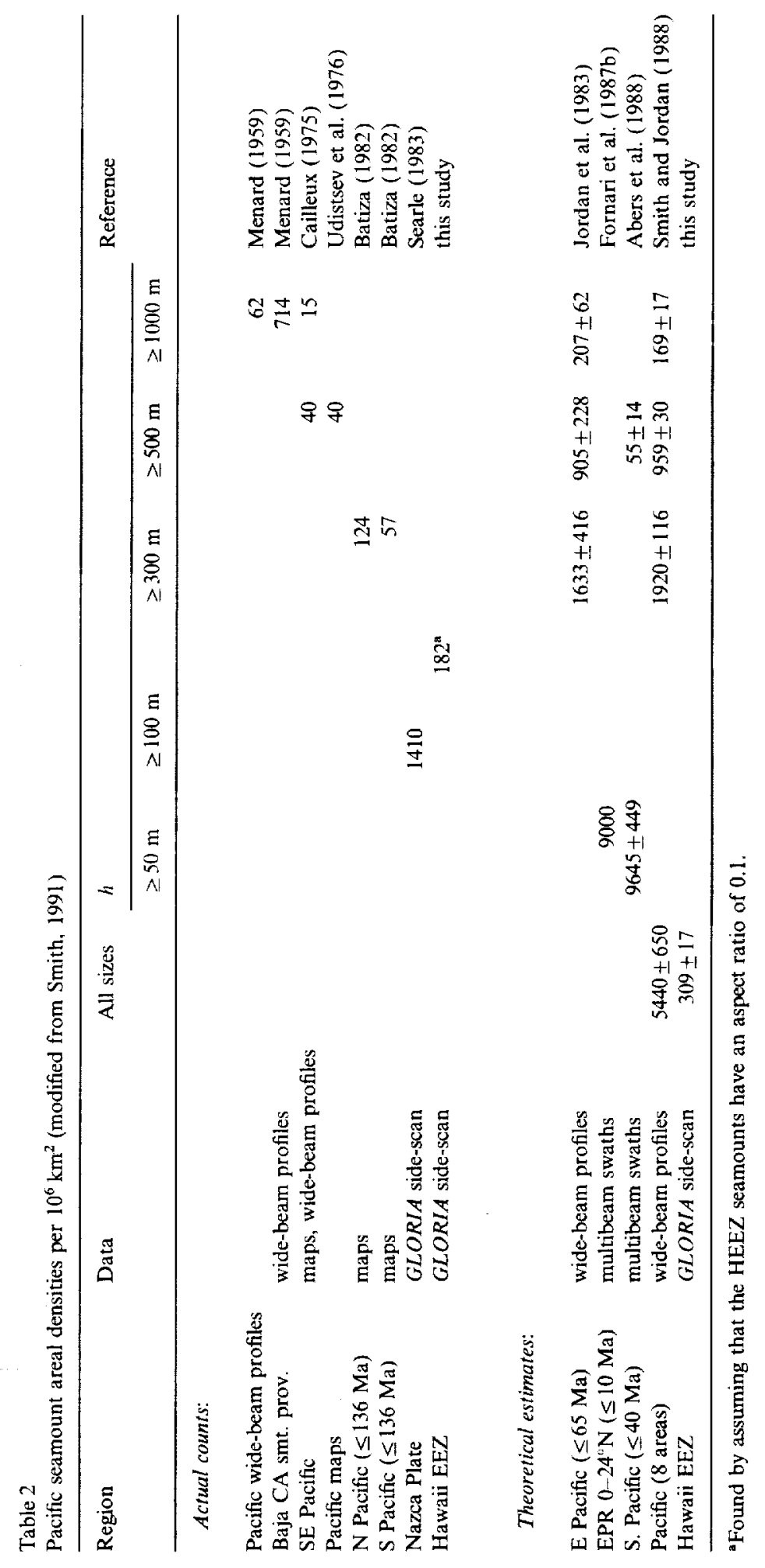


trasts across the fracture zones can be explained in two ways (Bemis and Smith, 1993): (1) at the EPR, more seamounts were produced on one side of a fracture zone than on the other side; and (2) volcanic production was episodic through time at the EPR, resulting in different seamount abundances on crust of different age.

Localized igneous activity since leaving the EPR could also contribute to the greater abundance of seamounts between the Murray and Molokai FZ's. Some of the Musicians seamounts in this region are up to $15 \mathrm{Myr}$ younger than the crust upon which they rest and may result from an old hotspot that resided off-axis from the ancestral EPR (Pringle, 1993). The Pliocene Pleistocene North Arch lava flows show that even more recent igneous activity has occurred in this region. The lithosphere in this region is younger and thinner than that on the other side of the fracture zones and may allow more decompression melting from a hotspot source (Phipps Morgan et al., 1995). Finally, the GLORIA images show that some seamounts in the region are aligned next to and along the same trend as the Necker Ridge, suggesting a contemporaneous age that is younger than the underlying crust. Thus, in addition to the dated Musicians, other seamounts may be young. However, unequivocal resolution of the question of whether or not great abundances of young seamounts exist must await future sample collection and analysis.

Two factors may account for the overall low relative abundance of HEEZ seamounts. The first is sediment cover. Sediment thickness is, on average, less in areas 1 and 2 of Smith and Jordan (1988) than in the HEEZ (Winterer, 1989). There are no strong variations in biological productivity between these regions, so that the main reason for the contrast in thickness is the younger crust in areas 1 and 2. Assuming a sediment deposition rate of $2.5 \mathrm{~m} / \mathrm{Myr}$ (Moore et al., 1994) and an age of HEEZ crust between 72 Ma (magnetic anomaly 33) and $130 \mathrm{Ma}$ (anomaly M10) (Atwater and Severinghaus, 1988), sediment cover on EPRderived HEEZ seamounts should range from 180 to $325 \mathrm{~m}$. This estimate is consistent with $235 \mathrm{~m}$ of sediment found in cores from Ocean Drilling Program Sites 842 and 843 south of the Hawaiian
Arch at $19^{\circ} \mathrm{N}, 159^{\circ} \mathrm{W}$ (Hull, 1993). Assuming the HEEZ seamounts have aspect ratios of $0.1,250 \mathrm{~m}$ of sediment should decrease their diameters by $2.5 \mathrm{~km}$ and bury them completely if they are smaller. The low backscatter of sediment relative to basalt should make buried seamounts difficult to see in GLORIA imagery, even if some topographic signature is preserved. If this sediment is "removed" by increasing the diameter of the seamounts by $2.5 \mathrm{~km}, v_{0}$ nearly doubles to $576 \pm 58$ seamounts $10^{6} \mathrm{~km}^{2}$. This value is still far lower than the values of Smith and Jordan (1988). Furthermore, the estimate is too liberal if some of the seamounts formed since leaving the EPR, because they should have less sediment cover.

The different methods used to identify seamounts are probably a significant additional factor. Smith and Jordan (1988) used bathymetric tracks, not visual imagery, for identification. In the earlier studies, misidentification of volcanoes or erroneous assumptions in extrapolating bathymetric tracks to large areas could have overestimated the number of seamounts. In contrast, the criteria in this study are strictly visual. Seamounts with sonar-brightnesses similar to the surrounding seafloor should be virtually invisible on the GLORIA mosaic. Thus, this study may underestimate the number of seamounts.

The relative lack of and small size of seamounts near the Murray and Molokai FZ's (Figs. 1 and $9 \mathrm{~b}, \mathrm{c})$ is inconsistent with other areas of the Pacific where this has been studied. Based on their analysis of the distribution of seamounts near the EPR on the Cocos Plate, Batiza and Vanko (1983) proposed that magma ascent and seamount production are favored near fracture zones. However, Scheirer and Macdonald (1995) found that the heights and abundances of seamounts near EPR discontinuities are indistinguishable from those near mid-segments. A lack of seamounts near fracture zones might be caused by a reduction in magma supply or mantle upwelling near spreading axis discontinuities (Scheirer and Macdonald, 1995). Whether or not this applies to the HEEZ portion of the Murray and Molokai FZ's when they were near the ancestral EPR is uncertain. As discussed elsewhere in this paper, it is likely that some seamounts in the HEEZ formed after leaving 
the EPR, making the interpretation of seamount distribution near the fracture zones somewhat ambiguous. At the very least, it is clear that fracture zones need not necessarily be loci for seamount production.

\subsection{Dimensions}

Diameters of the HEEZ seamounts are similar to those elsewhere in the Pacific. In both regions, abundance is inversely proportional to diameter as discussed previously in relation to Eq. (1). This is further illustrated in Fig. 10, where the fraction of seamounts as a function of diameter in the HEEZ is compared to seamounts near the EPR between $8^{\circ}$ and $17^{\circ} \mathrm{N}$ (Scheirer and Macdonald, 1995) and on the Nazca Plate (Searle, 1983). In the case of the HEEZ and Nazca, the latter of which was also studied with GLORIA, the bin with the greatest abundance is $2-4 \mathrm{~km}$. The bin with greatest abundance in the EPR study is between 4 and $6 \mathrm{~km}$. In all three cases abundances decline fairly systematically away from the modal bin. The decline at lower sizes is likely due to resolution limitations.

The characteristic diameter $\left(\alpha^{-1}\right)$ of the HEEZ seamounts is $4.16 \pm 0.11 \mathrm{~km}$ compared to $3.17 \pm 0.4 \mathrm{~km}$ estimated for the whole Pacific (Jordan et al., 1983; Smith and Jordan, 1988). Converting the characteristic heights of Smith and Jordan (1988) to characteristic diameters by assuming a typical seamount aspect ratio of 0.1 (Smith, 1988) yields an $\alpha^{-1}$ of $2.57 \pm 0.38$ and $3.08 \pm 0.67 \mathrm{~km}$ for their areas 1 and 2 , respectively (Table 1). Area 1, between the Clarion and Murray FZ's, is tectonically analogous to the HEEZ regions between the Molokai and Murray FZ's and SE of the Molokai FZ, which have characteris-

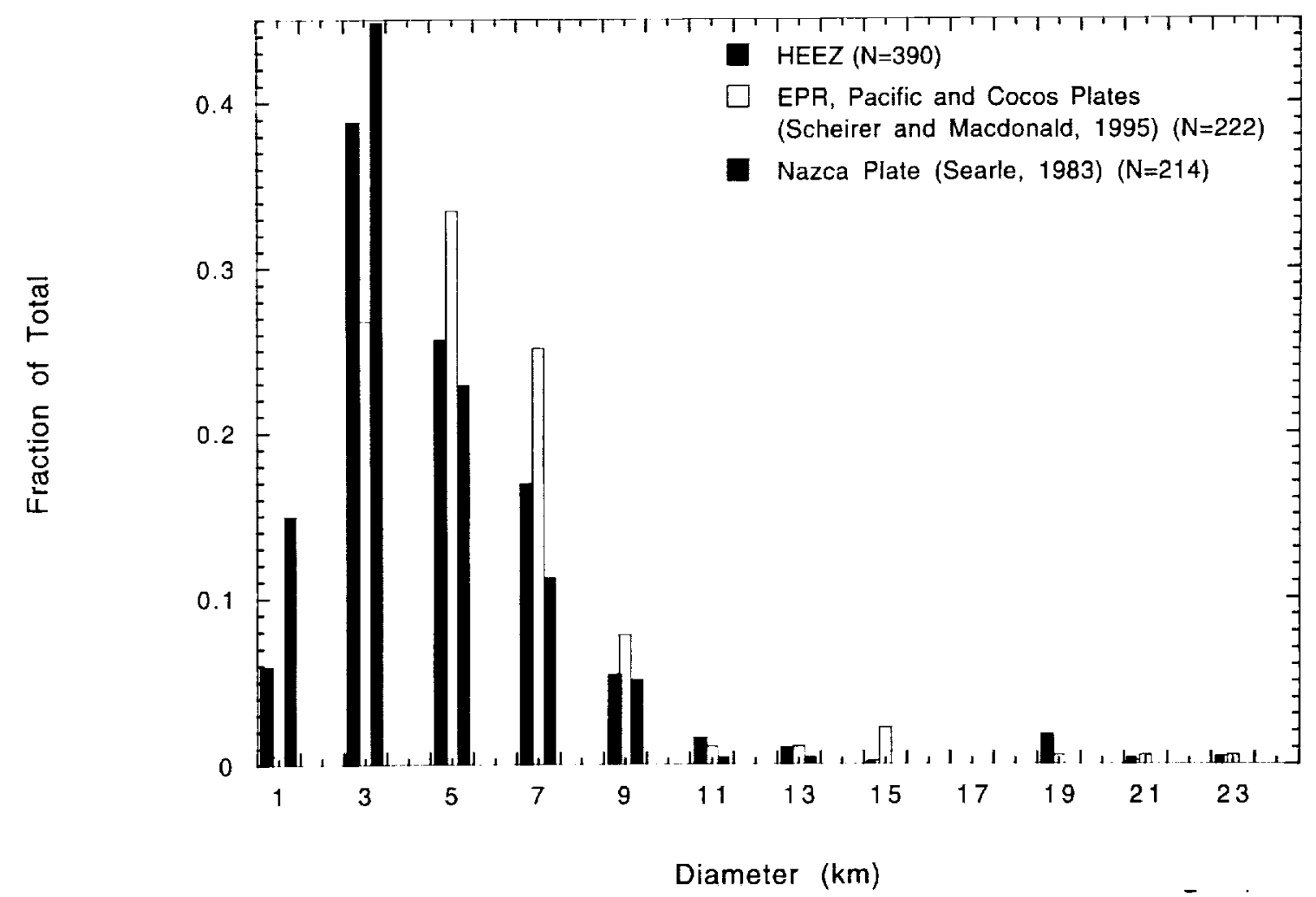

Fig. 10. Fractional abundance of other Pacific and HEEZ seamounts as a function of diameter. Diameters are binned for $\pm 1 \mathrm{~km}$ from the value shown on the $x$-axis, the lower bound being inclusive and the upper exclusive. 
tic diameters of $4.48 \pm 0.13$ and $4.88 \pm 0.32 \mathrm{~km}$, respectively. NW of the Murray $\mathrm{FZ}, x^{-1}$ is $17.7 \pm 0.4 \mathrm{~km}$, considerably greater than the value of $3.08 \pm 0.67 \mathrm{~km}$ found in Smith and Jordan's area 2 (between the Murray and Mendocino FZ's). At face value, these statistics indicate that seamount abundance increases less with decreasing diameter in the HEEZ compared to analogous regions in the Pacific and the Pacific overall. This cannot be explained by thicker sediment in the HEEZ, because sediment deposition should uniformly lower diameters, decreasing the estimated number of seamounts of all sizes per unit area $\left(v_{0}\right)$, but not altering the slope of the abundance-diameter distribution $[\exp (-x D)]$. The relatively high characteristic diameters in the HEEZ are therefore indicative of either a lower seamount abundance compared to the rest of the Pacific or, as discussed previously, differences between the identification methods used in this study and that of Smith and Jordan (1988).

\subsection{Morphology}

The shapes of Pacific seamounts vary, and the nomenclature and classification schemes differ from author to author. Common categories are "cones", "truncated cones", "shields", and "flattopped volcanoes". Guyots and some seamounts are commonly described as having "star" or "starfish" shapes. The classes of HEEZ seamounts identified here, the "cones", amorphous "heaps", "pancakes", and "stars" represent fairly well the range of seamount morphologies in the Pacific, both near the rise axis and in intraplate settings.

At the EPR, the range of seamount sizes increases with distance from the axis. Only small constructs are near the axis and an increasing number of larger ones are found farther away (Smith and Jordan, 1988; Scheirer and Macdonald, 1995). Similarly, morphology changes from mainly small conical and dome-shaped seamounts near the axis to an increasing abundance of irregular and polygonal volcanoes at greater distances to those with "upturned soup bowl" shapes (flattopped with convex upward flanks) in the outermost regions (Fornari et al., 1984, 1987a). The small conical volcanoes probably are equivalent to the HEEZ cones and the dome-shaped volcanoes are similar to the heaps and some pancakes. The "upturned soup bowls" are closest to the HEEZ pancakes in morphology. If seamounts form close together, they may form volcanic ridges (Batiza, 1989), analogous to the "ridge mounds" identified here. If the seamounts are large, the development of flank rift zones may give them star-like shapes in planview like those seen here (although this morphology has mostly been attributed to guyots) (Batiza and Vanko, 1983; Vogt and Smoot, 1984; Batiza, 1989; Mammerickx, 1989).

Most seamounts in the Pacific Plate interior were formed near, then transported away from the EPR (Fornari et al., 1987b; Abers et al., 1988; Smith and Jordan, 1988; Smith, 1991). Thus, it is not surprising that the morphology of seamounts in intraplate settings is similar to that of seamounts near the spreading center. For example, the occurrence of dome and truncated cone shaped volcanoes within the Pacific Plate is common. Hollister et al. (1978) noted a concentration of the former in the Philippine Sea and the latter in the northwest Pacific. Searle (1983) found 214 intraplate seamounts greater than $1 \mathrm{~km}$ wide in GLORIA images of the Nazca Plate. Of the volcanoes more than $4 \mathrm{~km}$ in diameter, $70 \%$ consist of steep-sided (mean and maximum slopes of $18^{\circ}$ and $36^{\circ}$, respectively), "truncated cones" with summit plateaus that are slightly concave upward.

Most of the secondary features of the HEEZ seamounts have been documented in other regions as well. Calderas or craters on seamounts are common in some regions (Searle, 1983; Fornari et al., 1984, 1987a). For example, Searle (1983) found that out of the 214 seamounts surveyed by GLORIA on the Nazca Plate, $\sim 45 \%$ had "calderas" (defined as depressions greater than $1 \mathrm{~km}$ in diameter) or "craters" ( $<1 \mathrm{~km}$ wide). This compares to $17 \%$ found in this study. In contrast, summit depressions are completely lacking in other areas, such as the western Pacific and Philippine Basin at depths between 2000 and $5000 \mathrm{~m}$ (Hollister et al., 1978). The smaller mounds found on $\sim 10 \%$ of the HEEZ seamounts (Figs. $2 \mathrm{~g}$ and h) may in many cases be comparable to spine-like bulges that project through the sediment at other intra-plate Pacific volcanoes (e.g., Hollister et al., 
1978). Examples of coalesced seamounts (Figs. 2c and $g$ ) exist in other Pacific locales as well (Batiza and Vanko, 1983; Searle, 1983). Searle (1983) found that at least $4 \%$ of the seamounts imaged by GLORIA on the Nazca Plate have overlapping relations. This matches the $4 \%$ value found for the Hawaii EEZ. Features interpreted as landslides (Fig. 2h) may exist on other Pacific seamounts too (Searle, 1983). Normal faults on seamounts, such as those splitting some of the seamounts in the HEEZ ( Fig. 2i), are also found on seamounts atop EPR-parallel faults and fissures (Fornari et al., 1987a; Edwards et al., 1991) and in intra-plate settings (Searle, 1983). However only one seamount graben, that striking NW-SE, has an orientation expected for extensional stresses caused by seafloor spreading or lithospheric flexure. To the best of this author's knowledge volcanoes that look like the HEEZ seamounts with truncated edges (Fig. 2b) have not been reported elsewhere, although this is not surprising considering their rarity in the HEEZ. Unfortunately, multibeam bathymetry and side-scan sonar from multiple angles needed to better characterize this enigmatic class of seamounts are unavailable.

\section{Discussion}

The similarity between the morphology and dimensions of HEEZ seamounts and those elsewhere in the Pacific suggests that their modes of formation were similar. Two end-member models have been proposed for the formation of seamounts at the EPR which account for the change in size and morphology of near-axis seamounts with distance from the axis (Fornari et al., 1984, 1987a; Smith and Jordan, 1988; Batiza, 1989; Scheirer and Macdonald, 1995): (1) all seamounts form near the axis and evolve as they are carried away by plate motion (Fornari et al., 1984, 1987a; Batiza, 1989; Scheirer and Macdonald, 1995), or (2) the time interval over which seamounts form is relatively short, so that their size and morphology are dependent on their distance from the rise (Barone and Ryan, 1990). The GLORIA data alone cannot determine which model is more applicable to the HEEZ seamounts.
However, the alignment of seamounts along trends parallel to the Necker Ridge and the high areal density of seamounts between the Murray and Molokai FZ's seen in the GLORIA images suggest that post-EPR igneous processes were not limited to the formation of some of the Musician seamounts (Pringle, 1993) or the large Pliocene-Pleistocene North Arch flow field (Clague et al., 1990). There are no discernible differences in morphology between these seamounts and those aligned with the fracture zones, which probably formed at the EPR. Thus, submarine volcanism in the plate interior seems capable of producing seamounts similar to those seen near spreading centers, regardless of the exact mechanism by which this occurs.

The question of to what extent intraplate seamount volcanism has occurred off-axis from the Hawaiian Ridge has important implications for the volcanic-tectonic history of the crust near Hawaii. Although this study documents the characteristics of HEEZ seamounts and strongly suggests that previously undocumented post-EPR seamounts exist, more definitive data are needed. Samples are sorely needed from these seamounts to find out if they derive from near the ancestral EPR or formed later. Geochemistry and ages must be determined. The limited sampling to date indicates that seamounts born near the EPR, including the Musicians, derive from a more depleted mantle source than volcanoes in the Hawaiian chain (Batiza and Vanko, 1984; Hess, 1989; Pringle, 1992, 1993; Pringle et al., 1990). The North Arch lavas also seem to derive from a relatively depleted mantle source but are more alkalic than the majority of Hawaiian lavas (Clague et al., 1990). Thus, geochemical analyses should help determine where the seamounts formed. A more unequivocal test of seamount origin is dating. Radiometric and paleomagnetic (for seamounts not formed during the Cretaceous quiet interval) ages can be determined for relatively unaltered samples. Thickness of sediment cover, thickness of weathering rinds, and dating of sediment in contact with the samples can also be used to estimate age. Dating of the seamounts will determine if the seamounts formed on the periphery of the EPR, near the Hawaiian 
chain, or somewhere in between. Clearly, much important and exciting work remains.

\section{Acknowledgements}

Comments from two anonymous reviewers substantially improved this paper. Critiques of this work at intermediate stages by John Dvorak, George McGill, Daniel Sheirer, and Debbie Smith are much appreciated. This project began while I was an employee of the U.S. Geological Survey, Menlo Park, Californa. Jim Moore suggested this study and, with Bill Normark, supported my access to the GLORIA data. They provided guidance through the data collection stage of the project and reviewed preliminary versions of the manuscript. Chris Gutmacher and Michael Torresan made available raw bathymetry data and Tom Chase and Carolyn Degnan provided bathymetric maps. Debbie Smith helped with the statistical analyses and provided the computer code for determining statistical parameters. Conversations with Rodey Batiza and David Clague were very useful. Finally, this study would not have been possible without acquisition of the Hawaiian EEZ sidescan sonar data and for this I am grateful to the entire U.S. Geological Survey GLORIA team. Partial support was provided by NASA grant NAGW-4263 to the University of Massachusetts.

\section{Appendix A}

Listed are data for the seamounts in the HEEZ examined in this study. Longitudes and latitudes are shown to $0.1^{\circ}$ although in some cases the accuracy is coarser. Diameters are the average of maximum and minimum widths.

\begin{tabular}{|c|c|c|c|c|c|}
\hline ID & $\begin{array}{l}\text { Lat. } \\
\text { (N) }\end{array}$ & $\begin{array}{l}\text { Long. } \\
\text { (W) }\end{array}$ & Type & Secondary feature(s) & $\begin{array}{l}\text { Ave. dia } \\
(\mathrm{km})\end{array}$ \\
\hline \multicolumn{6}{|c|}{ NW of Murray: } \\
\hline I & 27.9 & 167.6 & heap & crater $(\mathrm{s})$ & 8.8 \\
\hline 2 & 27.7 & 167.8 & heap & graben & 7.5 \\
\hline 3 & 27.3 & 168.0 & heap & crater(s) & 4.4 \\
\hline 4 & 28.1 & 170.2 & pancake & & 2.5 \\
\hline 5 & 29.0 & 171.6 & cone & summit mound & 3.3 \\
\hline 6 & 28.6 & 171.9 & pancake & summit mound & 5.7 \\
\hline 7 & 28.6 & 172.0 & pancake & coalesced, summit mound & 8.8 \\
\hline 8 & 28.5 & 172.3 & heap & & 7.0 \\
\hline 9 & 28.7 & 172.9 & pancake & & 3.8 \\
\hline 10 & 27.4 & 173.3 & pancake & & 3.8 \\
\hline I1 & 29.2 & 174.7 & pancake & crater $(\mathrm{s})$, truncated & 4.3 \\
\hline 12 & 29.4 & 174.8 & pancake & & 3.6 \\
\hline 13 & 29.1 & 174.9 & heap & crater(s) & 8.2 \\
\hline 14 & 29.6 & 175.0 & pancake & & 5.0 \\
\hline I5 & 29.6 & 175.1 & pancake & & 4.0 \\
\hline 16 & 24.0 & 175.5 & pancake & & 6.1 \\
\hline 17 & 23.9 & 175.8 & pancake & & 2.6 \\
\hline 18 & 25.6 & 175.9 & pancake & & 2.9 \\
\hline 19 & 26.9 & 176.0 & heap & & 18.3 \\
\hline 20 & 29.6 & 176.2 & pancake & summit mound & 6.3 \\
\hline 21 & 30.7 & 176.3 & cone & & 5.3 \\
\hline 22 & 30.6 & 176.3 & heap & & 4.9 \\
\hline 23 & 30.6 & 176.3 & heap & coalesced & 4.5 \\
\hline 24 & 30.6 & 176.5 & pancake & & 8.1 \\
\hline 25 & 30.5 & 176.8 & pancake & & 5.3 \\
\hline
\end{tabular}


Appendix A (continued)

\begin{tabular}{|c|c|c|c|c|c|}
\hline ID & $\begin{array}{l}\text { Lat. } \\
(\mathrm{N})\end{array}$ & $\begin{array}{l}\text { Long. } \\
\text { (W) }\end{array}$ & Type & Secondary feature(s) & $\begin{array}{l}\text { Ave dia. } \\
(\mathrm{km})\end{array}$ \\
\hline 26 & 31.4 & {$[76.9$} & pancake & & 4.8 \\
\hline 27 & 30.5 & 176.9 & heap & crater(s) & 4.8 \\
\hline 28 & 30.7 & 177.1 & pancake & & 4.5 \\
\hline 29 & 31.3 & {$[77.1$} & pancake & & 3.5 \\
\hline 30 & 31.3 & {$[77.1$} & pancake & & 5.9 \\
\hline 31 & 30.5 & 177.2 & heap & & 3.3 \\
\hline 32 & 25.6 & 177.2 & heap & & 19.4 \\
\hline 33 & 32.0 & 177.4 & cone & & 3.9 \\
\hline 34 & 29.8 & 177.4 & pancake & & 8.0 \\
\hline 35 & 24.7 & 177.7 & pancake & & 5.8 \\
\hline 36 & 26.2 & 177.8 & heap? & & 22.8 \\
\hline 37 & 27.7 & {$[77.9$} & pancake & crater(s) & 6.6 \\
\hline 38 & 29.6 & 178.0 & pancake & & 7.8 \\
\hline 39 & 32.0 & 178.1 & pancake & landslide & 1.9 \\
\hline 40 & 29.6 & 178.3 & pancake & landslide, summit mound & 4.8 \\
\hline 41 & 27.0 & 178.4 & pancake & & 4.9 \\
\hline 42 & 31.0 & 178.5 & pancake & & 1.7 \\
\hline 43 & 26.8 & 178.7 & pancake & crater(s), summit mound & 4.4 \\
\hline 44 & 25.5 & 179.0 & pancake & & 3.4 \\
\hline 45 & 30.7 & 179.1 & pancake & summit mound & 4.0 \\
\hline 46 & 25.7 & 179.3 & pancake & crater(s) & 8.8 \\
\hline 47 & 27.6 & 179.4 & heap & crater(s), landslide & 5.0 \\
\hline 48 & 30.3 & 179.5 & pancake & & 5.2 \\
\hline 49 & 26.4 & 179.6 & pancake & crater(s) & 4.3 \\
\hline 50 & 29.4 & 179.8 & pancake & summit mound & 4.1 \\
\hline 51 & 25.9 & 179.8 & heap & & 22.8 \\
\hline 52 & 27.4 & 179.9 & pancake & summit mound & 6.3 \\
\hline 53 & 27.5 & 180.0 & pancake & & 1.9 \\
\hline 54 & 25.4 & 180.0 & pancake & summit mound & 5.1 \\
\hline 55 & 27.4 & 180.2 & heap & summit mound & 4.0 \\
\hline 56 & 26.5 & 180.7 & heap & & 4.8 \\
\hline 57 & 28.3 & 180.8 & pancake & crater(s) & 3.0 \\
\hline 58 & 26.0 & 180.9 & pancake & coalesced & 7.4 \\
\hline 59 & 30.6 & 181.1 & pancake & crater(s), summit mound & 6.1 \\
\hline 60 & 26.6 & 181.2 & pancake & summit mound & 7.5 \\
\hline 61 & 27.1 & 181.2 & pancake & & 6.9 \\
\hline 62 & 29.9 & 181.6 & pancake & summit mound & 4.9 \\
\hline 63 & 28.2 & 181.6 & pancake & & 6.0 \\
\hline 64 & 27.4 & 181.6 & pancake & & 4.4 \\
\hline 65 & 29.6 & 181.8 & pancake & summit mound & 7.8 \\
\hline 66 & 28.0 & 182.0 & heap & crater & 29.7 \\
\hline 67 & 27.7 & 182.0 & pancake & crater(s), landslide & 6.3 \\
\hline \multicolumn{6}{|c|}{ Between Murray and Molakai: } \\
\hline 68 & 23.3 & 154.0 & heap & crater(s) & 1,2 \\
\hline 69 & 23.2 & 154.0 & heap & & 2.6 \\
\hline 70 & 23.3 & 154.0 & heap & & 3.6 \\
\hline 71 & 23.3 & 154.0 & heap & & 2.7 \\
\hline 72 & 23.3 & 154.1 & heap & & 2.2 \\
\hline 73 & 23.2 & 154.4 & pancake & & 3.6 \\
\hline 74 & 22.3 & 154.5 & pancake & summit mound & 4.4 \\
\hline 75 & 23.1 & 154.5 & pancake & & 2.5 \\
\hline
\end{tabular}


Appendix A (contimued)

\begin{tabular}{|c|c|c|c|c|c|}
\hline ID & $\begin{array}{l}\text { Lat. } \\
(\mathrm{N})\end{array}$ & $\begin{array}{l}\text { Long. } \\
\text { (W) }\end{array}$ & Type & Secondary feature(s) & $\begin{array}{l}\text { Ave. dia. } \\
(\mathrm{km})\end{array}$ \\
\hline 76 & 23.3 & 154.7 & heap & & 2.0 \\
\hline 77 & 22.4 & 154.8 & heap & & 7.6 \\
\hline 78 & 22.5 & $\mathrm{I} 55.0$ & heap & & 2.8 \\
\hline 79 & 23.5 & 155.0 & pancake & crater(s) & 7.0 \\
\hline 80 & 20.8 & 155.1 & cone & & 2.1 \\
\hline 81 & 22.6 & 155.1 & pancake & crater(s) & 6.6 \\
\hline 82 & 20.6 & 155.2 & pancake & & 3.1 \\
\hline 83 & 23.5 & 155.2 & heap & & 3.8 \\
\hline 84 & 22.7 & 155.3 & heap & crater(s) & 7.2 \\
\hline 85 & 23.4 & 155.4 & heap & & 5.2 \\
\hline 86 & 23.8 & 155.8 & cone & & 3.8 \\
\hline 87 & 23.9 & 155.9 & pancake & & 3.3 \\
\hline 88 & 23.7 & 155.9 & cone & & 2.6 \\
\hline 89 & 23.0 & 156.0 & heap & & 7.8 \\
\hline 90 & 23.7 & 156.0 & cone & & 2.0 \\
\hline 91 & 23.0 & 156.0 & heap & landslide & 7.8 \\
\hline 92 & 23.3 & 156.6 & cone & & 5.8 \\
\hline 93 & 23.7 & 156.7 & heap & & 4.0 \\
\hline 94 & 23.4 & 156.7 & cone & & 2.0 \\
\hline 95 & 23.4 & 156.8 & heap & & 2.0 \\
\hline 96 & 23.4 & 156.8 & heap & & 3.2 \\
\hline 97 & 23.5 & 156.8 & cone & $\operatorname{crater}(\mathrm{s})$ & 5.8 \\
\hline 98 & 23.4 & 156.8 & conc & crater(s) & 2.2 \\
\hline 99 & 23.4 & 156.8 & cone & & 2.6 \\
\hline 100 & 24.4 & 156.8 & heap & & 6.2 \\
\hline 101 & 23.4 & 156.9 & heap & summit mound & 1.8 \\
\hline 102 & 23.2 & 156.9 & cone & & 2.8 \\
\hline 103 & 23.2 & 156.9 & cone & & 1.6 \\
\hline 104 & 24.0 & 156.9 & pancake & landslide & 7.2 \\
\hline 105 & 23.2 & 156.9 & cone & & 2.0 \\
\hline 106 & 23.2 & 156.9 & cone & & 2.6 \\
\hline 107 & 23.8 & 156.9 & heap & & 6.8 \\
\hline 108 & 23.3 & 157.0 & cone & & 3.0 \\
\hline 109 & 24.4 & 157.0 & pancake & & 6.4 \\
\hline 110 & 23.8 & 157.0 & pancake & & 6.2 \\
\hline 111 & 23.1 & 157.0 & heap & & 3.4 \\
\hline 112 & 23.8 & 157.1 & heap & & 4.7 \\
\hline 113 & 23.1 & 157.1 & pancake & & 2.0 \\
\hline 114 & 23.3 & 157.1 & pancake & & 6.6 \\
\hline 115 & 23.1 & 157.1 & heap & & 3.2 \\
\hline 116 & 23.2 & 157.2 & pancake & & 5.2 \\
\hline 117 & 23.6 & 157.2 & pancake & crater(s) & 4.4 \\
\hline 118 & 24.9 & 157.6 & heap & crater(s) & 14.1 \\
\hline 119 & 23.8 & 157.6 & heap & & 3.4 \\
\hline 120 & 23.9 & 157.6 & heap & crater(s) & 2.8 \\
\hline 121 & 24.9 & 157.6 & pancake & & 2.8 \\
\hline 122 & 23.4 & 157.7 & heap & & 4.4 \\
\hline 123 & 23.4 & 157.7 & pancake & & 4.8 \\
\hline 124 & 24.6 & 157.8 & heap & coalesced & 7.6 \\
\hline 125 & 24.7 & 157.9 & heap & & 10.3 \\
\hline 126 & 24.2 & 158.0 & heap & & 3.6 \\
\hline 127 & 24.2 & 158.0 & heap & & 6.6 \\
\hline 128 & 24.1 & 158.1 & heap & & 7.2 \\
\hline
\end{tabular}


Appendix A (continued)

\begin{tabular}{|c|c|c|c|c|c|}
\hline ID & $\begin{array}{l}\text { Lat. } \\
(\mathrm{N})\end{array}$ & $\begin{array}{l}\text { Long. } \\
\text { (W) }\end{array}$ & Type & Secondary feature(s) & $\begin{array}{l}\text { Ave. dia. } \\
(\mathrm{km})\end{array}$ \\
\hline 129 & 24.6 & 158.1 & pancake & summit mound & 5.2 \\
\hline 130 & 24.5 & 158.4 & heap & & 3.6 \\
\hline 131 & 24.5 & $\mathrm{I} 58.4$ & cone & & 3.8 \\
\hline 132 & 24.5 & 158.4 & pancake & crater(s) & 3.4 \\
\hline I 33 & 24.3 & 158.5 & heap & Iandslide & 4.4 \\
\hline I34 & 24.5 & 158.6 & cone & & 3.8 \\
\hline 135 & 23.5 & 158.7 & pancake & & 10.3 \\
\hline 136 & 24.3 & 158.7 & pancake & & 2.9 \\
\hline 137 & 24.7 & 158.7 & cone & & 4.0 \\
\hline 138 & 23.7 & 158.8 & heap & & 7.2 \\
\hline 139 & 23.4 & 158.9 & pancike & crater(s) & 7.6 \\
\hline 140 & 23.7 & 158.9 & heap & & 2.5 \\
\hline 141 & 23.6 & 158.9 & pancake & & 3.8 \\
\hline 142 & 23.5 & 158.9 & pancake & & 4.4 \\
\hline I43 & 24.7 & 158.9 & pancake & & 4.0 \\
\hline 144 & 25.2 & 159.1 & heap & & 2.8 \\
\hline 145 & 23.6 & 159.1 & pancake & summit mound & 4.2 \\
\hline 146 & 23.7 & 159.1 & heap & truncated & 4.2 \\
\hline 147 & 25.2 & 159.1 & heap & & 3.8 \\
\hline 148 & 23.8 & 159.2 & heap & crater(s) & 3.6 \\
\hline 149 & 23.5 & 159.2 & heap & & 4.5 \\
\hline 150 & 23.6 & 159.2 & pancake & summit mound & 3.2 \\
\hline 151 & 23.7 & 159.2 & heap & coalesced & 9.5 \\
\hline 152 & 24.0 & 159.2 & pancake & crater(s) & 4.8 \\
\hline 153 & 24.0 & 159.3 & heap & & 5.0 \\
\hline 154 & 24.1 & 159.3 & pancake & $\operatorname{crater}(\mathrm{s})$ & 4.4 \\
\hline 155 & 24.1 & 159.3 & heap & & 2.2 \\
\hline 156 & 24.1 & 159.3 & heap & & 2.2 \\
\hline 157 & 24.1 & 159.4 & heap & & 2.8 \\
\hline 158 & 24.1 & 159.4 & heap & & 3.8 \\
\hline 159 & 24.1 & 159.4 & heap & & 2.7 \\
\hline 160 & 24.1 & 159.4 & pancake & & 2.0 \\
\hline 161 & 24.1 & 159.4 & heap & & 4.2 \\
\hline 162 & 24.1 & 159.4 & pancake & summit mound & 2.4 \\
\hline 163 & 25.3 & 159.5 & heap & & 1.8 \\
\hline 164 & 24.0 & 159.5 & heap & & 2.8 \\
\hline 165 & 25.3 & 159.5 & pancake & & 1.8 \\
\hline 166 & 25.3 & 159.5 & pancake & & 1.2 \\
\hline 167 & 25.3 & 159.5 & conc & & 2.0 \\
\hline 168 & 23.7 & 159.6 & pancake & coalesced & 8.2 \\
\hline 169 & 24.4 & 159.6 & pancake & & 4.4 \\
\hline 170 & 25.3 & 159.6 & heap & & 4.2 \\
\hline 171 & 25.2 & 159.6 & cone & & 2.2 \\
\hline 172 & 25.2 & 159.6 & cone & & 2.4 \\
\hline 173 & 25.2 & 159.7 & cone & & 2.4 \\
\hline 174 & 25.2 & 159.7 & cone & & 1.3 \\
\hline 175 & 25.2 & 159.7 & cone & & 2.0 \\
\hline 176 & 23.7 & 159.7 & pancake & summit mound & 6.0 \\
\hline 177 & 25.1 & 159.7 & pancake & & 3.0 \\
\hline 178 & 24.1 & 159.7 & pancake & & 4.2 \\
\hline 179 & 25.3 & 159.7 & pancake & coalesced & 3.6 \\
\hline 180 & 23.7 & 159.8 & pancake & summit mound & 5.6 \\
\hline 181 & 24.5 & 159.9 & heap & & 5.8 \\
\hline
\end{tabular}


Appendix A (continued)

\begin{tabular}{|c|c|c|c|c|c|}
\hline ID & $\begin{array}{l}\text { Lat. } \\
\left({ }^{\circ}\right)\end{array}$ & $\begin{array}{l}\text { Long. } \\
\text { (W) }\end{array}$ & Type & Secondary feature(s) & $\begin{array}{l}\text { Ave. dia. } \\
(\mathrm{km})\end{array}$ \\
\hline 182 & 24.7 & 159.9 & pancake & & 3.4 \\
\hline 183 & 24.2 & 160.0 & heap & coalesced & 6.0 \\
\hline 184 & 23.9 & 160.0 & cone & & 2.4 \\
\hline 185 & 23.7 & 160.0 & pancake & summit mound & 5.6 \\
\hline 186 & 24.1 & 160.0 & heap & & 2.2 \\
\hline 187 & 24.1 & 160.0 & cone & & 2.4 \\
\hline 188 & 23.9 & 160.0 & heap & & 2.2 \\
\hline 189 & 23.9 & 160.0 & cone & & 1.6 \\
\hline 190 & 24.6 & 160.0 & heap & & 2.4 \\
\hline 191 & 24.2 & 160.1 & pancake & coalesced & 2.8 \\
\hline 192 & 24.2 & 160.1 & cone & & 2.2 \\
\hline 193 & 24.2 & 160.1 & heap & summit mound & 7.2 \\
\hline 194 & 24.6 & 160.1 & heap & & 2.8 \\
\hline 195 & 23.9 & 160.1 & pancake & & 1.4 \\
\hline 196 & 24.6 & 160.1 & heap & & 2.2 \\
\hline 197 & 23.9 & 160.1 & pancake & & 5.1 \\
\hline 198 & 24,2 & 160.1 & heap & & 4.0 \\
\hline 199 & 23.6 & 160.2 & pancake & & 5.6 \\
\hline 200 & 24.3 & 160.2 & heap & crater(s) & 2.0 \\
\hline 201 & 24.1 & 160.2 & cone & & 2.2 \\
\hline 202 & 24.2 & 160.2 & heap & & 2.4 \\
\hline 203 & 24.9 & 160.2 & pancake & crater(s) & 4.4 \\
\hline 204 & 24.1 & 160.3 & pancake & & 3.6 \\
\hline 205 & 24.1 & 160.3 & pancake & summit mound & 7.0 \\
\hline 206 & 23.8 & 160.3 & heap & crater(s) & 8.2 \\
\hline 207 & 24.8 & 160.5 & pancake & & 4.0 \\
\hline 208 & 24.8 & 160.5 & pancake & & 4.0 \\
\hline 209 & 24.0 & 160.6 & heap & crater(s) & 4.3 \\
\hline 210 & 23.8 & 160.7 & pancake & & 5.5 \\
\hline 211 & 25.2 & 160.7 & pancake & crater $(s)$, truncated & 4.3 \\
\hline 212 & 25.5 & 160.7 & pancake & & 3.6 \\
\hline 213 & 23.8 & 160.8 & heap & crater(s) & 10.5 \\
\hline 214 & 25.4 & 160.8 & pancake & & 1.5 \\
\hline 215 & 26.1 & 160.8 & pancake & crater (s) & 2.2 \\
\hline 216 & 19.4 & 160.9 & pancake & crater(s) & 3.9 \\
\hline 217 & 24.7 & 160.9 & pancake & truncated & 7.0 \\
\hline 218 & 25.2 & 160.9 & pancake & & 6.9 \\
\hline 219 & 25.5 & 161.0 & pancake & summit mound & 1.7 \\
\hline 220 & 24.8 & 161.1 & pancake & & 6.2 \\
\hline 221 & 25.3 & 161.2 & pancake & graben & 6.9 \\
\hline 222 & 26.1 & 161.2 & pancake & & 2.6 \\
\hline 223 & 26.5 & 161.8 & pancake & & 3.3 \\
\hline 224 & 24.6 & 161.8 & pancake & & 9.3 \\
\hline 225 (Mendelssohn) & 25.1 & 161.9 & ridge mound & & 57.0 \\
\hline 226 & 24.6 & 162.0 & pancake & & 4.1 \\
\hline 227 & 26.7 & 162.2 & pancake & & 4.3 \\
\hline 228 & 24.6 & 162.3 & pancake & & 7.3 \\
\hline 229 & 24.3 & 162.3 & pancake & & 6.3 \\
\hline 230 & 24.3 & 162.3 & pancake & & 6.6 \\
\hline 231 & 20.1 & 162.4 & cone & & 2.2 \\
\hline 232 & 19.0 & 162.4 & pancake & crater(s) & 7.2 \\
\hline 233 & 26.5 & 162.4 & pancake & & 3.1 \\
\hline 234 & 21.1 & 162.6 & pancake & & 4.2 \\
\hline
\end{tabular}


Appendix A (continued)

\begin{tabular}{|c|c|c|c|c|c|}
\hline ID & $\begin{array}{l}\text { Lat. } \\
\text { ( N) }\end{array}$ & $\begin{array}{l}\text { Long. } \\
\text { (W) }\end{array}$ & Type & Secondary reature(s) & $\begin{array}{l}\text { Ave. dia. } \\
(\mathrm{km})\end{array}$ \\
\hline 235 & 21.5 & 162.7 & heap? & & 12.6 \\
\hline 236 & 21.4 & 162.8 & heap? & & 18.2 \\
\hline 237 & 21.8 & 162.8 & star & & 12.6 \\
\hline 238 & 22.3 & 162.9 & star & & 18.2 \\
\hline 239 & 21.1 & 163.1 & heap? & & 13.7 \\
\hline 240 & 22.5 & 163.2 & star & & 19.4 \\
\hline 241 & 21.5 & 163.2 & pancake & & 8.9 \\
\hline 242 & 21.6 & 163.3 & pancake & summit mound & 8.9 \\
\hline 243 & 25.2 & 163.4 & pancake & crater(s) & 5.9 \\
\hline 244 & 22.7 & 163.5 & star & & 11.4 \\
\hline 245 & 21.1 & 163.6 & pancake & truncated & 6.8 \\
\hline 246 & 21.5 & 163.8 & heap & crater(s), summit mound & 6.1 \\
\hline 247 & 21.5 & 163.8 & pancake & crater(s), summit mound & 6.4 \\
\hline 248 & 20.9 & 164.0 & pancake & & 5.0 \\
\hline 249 & 20.9 & 164.1 & pancake & & 6.4 \\
\hline 250 & 24.5 & 164.1 & pancake & crater(s), summit mound & 5.2 \\
\hline 251 & 24.9 & 164.3 & heap & summit mound & 4.5 \\
\hline 252 & 25.8 & 164.3 & pancake & & 2.9 \\
\hline 253 & 25.3 & 164.3 & pancake & & 5.9 \\
\hline 254 & 24.9 & 164.5 & pancake & crater $(s)$, truncated & 8.8 \\
\hline 255 & 25.5 & 164.6 & pancake & & 2.8 \\
\hline 256 & 25.3 & 164.6 & pancake & coalesced & 5.8 \\
\hline 257 & 25.3 & 164.6 & pancake & coalesced & 5.9 \\
\hline 258 & 25.1 & 164.7 & pancake & & 5.3 \\
\hline 259 & 21.9 & 164.9 & heap & landslide & 2.8 \\
\hline 260 & 21.5 & 165.0 & pancake & crater $(s)$ & 6.6 \\
\hline 261 & 25.0 & 165.0 & pancake & graben & 2.9 \\
\hline 262 & 26.6 & 165.0 & pancake & coalesiced & 3.4 \\
\hline 263 & 26.7 & 165.1 & pancake & coalesced & 3.6 \\
\hline 264 & 26.6 & 165.3 & pancake & crater(s) & 3.1 \\
\hline 265 & 21.8 & 165.4 & pancake & summit mound & 3.1 \\
\hline 266 & 26.3 & 165.4 & heap & & 2.3 \\
\hline 267 & 22.4 & 166.0 & heap & crater(s) & 4.9 \\
\hline 268 & 20.5 & 166.0 & heap & crater (s) & 4.5 \\
\hline 269 & 20.9 & 166.0 & heap & summit mound & 7.0 \\
\hline 270 & 22.2 & 166.1 & heap & & 6.5 \\
\hline 271 & 20.9 & 166.2 & pancake & crater(s) & 7.6 \\
\hline 272 & 22.1 & 166.2 & pancake & crater(s) & 6.4 \\
\hline 273 & 21.5 & 166.3 & pancake & truncated & 3.0 \\
\hline 274 & 22.3 & 166.3 & pancake & & 5.5 \\
\hline 275 & 27.0 & 166.3 & pancake & crater(s) & 3.5 \\
\hline 276 & 22.1 & 166.3 & heap & & 5.8 \\
\hline 277 & 21.5 & 166.3 & pancake & & 5.5 \\
\hline 278 & 22.0 & 166.6 & pancake & & 9.3 \\
\hline 279 & 26.8 & 166.6 & pancake & crater(s) & 7.6 \\
\hline 280 & 22.1 & 166.7 & pancake & & 7.5 \\
\hline 281 & 22.9 & 167.0 & pancake & crater(s) & 6.3 \\
\hline 282 & 21.6 & 167.0 & pancake & & 3.9 \\
\hline 283 & 21.8 & 167.1 & pancake & & 9.5 \\
\hline 284 & 20.4 & 167.2 & pancake & & 2.5 \\
\hline 285 & 21.4 & 167.3 & pancake & & 4.3 \\
\hline 286 & 23.1 & 167.5 & pancake & & 6.5 \\
\hline 287 & 22.8 & 167.5 & pancake & & 3.3 \\
\hline
\end{tabular}


Appendix A (contimued)

\begin{tabular}{|c|c|c|c|c|c|}
\hline ID & $\begin{array}{l}\text { Lat. } \\
(\mathrm{N})\end{array}$ & $\begin{array}{l}\text { Long. } \\
\text { (W) }\end{array}$ & Type & Secondary feature(s) & $\begin{array}{l}\text { Ave. dia. } \\
(\mathrm{km})\end{array}$ \\
\hline 288 & 22.3 & 167.9 & pancake & & 3.6 \\
\hline 289 & 22.2 & 168.0 & pancake & & 4.7 \\
\hline 290 & 22.7 & 168.1 & pancake & & 1.6 \\
\hline 291 & 24.0 & 168.1 & pancake & & 1.9 \\
\hline 292 & 21.0 & 168.1 & pancake & & 4.9 \\
\hline 293 & 22.2 & 168.1 & pancake & & 2.4 \\
\hline 294 & 22.3 & 168.2 & pancake & & 2.6 \\
\hline 295 & 23.0 & 168.4 & pancake & & 8.4 \\
\hline 296 & 22.2 & 168.5 & pancake & & 3.8 \\
\hline 297 & 22.2 & 168.6 & pancake & & 2.6 \\
\hline 298 & 22.8 & 168.7 & pancake & truncated & 6.3 \\
\hline 299 & 22.8 & 168.9 & pancake & coalesced & 4.8 \\
\hline 300 & 22.6 & 169.0 & pancake & & 3.4 \\
\hline 301 & 22.8 & 169.0 & pancake & coalesced & 6.0 \\
\hline 302 & 23.1 & 169.4 & pancake & & 9.3 \\
\hline 303 & 22.8 & 169.5 & pancake & summit mound & 8.1 \\
\hline 304 & 22.0 & 169.5 & pancake & coalesced & 6.1 \\
\hline 305 & 22.0 & 169.5 & pancake & coalesced & 7.6 \\
\hline 306 & 21.8 & 169.7 & pancake & landslide & 7.3 \\
\hline 307 & 22.0 & 169.9 & pancake & & 8.3 \\
\hline 308 & 21.9 & 170.0 & pancake & & 7.6 \\
\hline 309 & 22.2 & 170.3 & pancake & & 8.9 \\
\hline 310 & 21.8 & 170.4 & pancake & & 6.8 \\
\hline 311 & 22.4 & 172.5 & pancake & & 6.8 \\
\hline 312 & 22.2 & 172.7 & pancake & & 4.4 \\
\hline 313 & 22.4 & 172.7 & pancake & & 6.4 \\
\hline 314 & 23.3 & 173.8 & pancake & $\operatorname{crater}(\mathrm{s})$ & 1.8 \\
\hline 315 & 23.6 & 173.8 & pancake & truncated & 5.8 \\
\hline 316 & 23.3 & 174.6 & heap & & 5.5 \\
\hline 317 & 23.1 & 174.9 & heap & $\operatorname{crater}(s)$ & 9.5 \\
\hline \multicolumn{6}{|c|}{ SE of Molakai: } \\
\hline 318 & 19.6 & 151.8 & pancake & crater(s) & 3.3 \\
\hline 319 & 18.4 & 151.9 & pancake & & 7.0 \\
\hline 320 & 21.3 & 152.0 & pancake & & 4.0 \\
\hline 321 & 20.8 & 152.0 & pancake & & 3.2 \\
\hline 322 & 20.9 & 152.1 & heap & crater(s) & 2.4 \\
\hline 323 & 18.6 & 152.9 & pancake & & 3.4 \\
\hline 324 & 17.8 & 152.9 & heap & crater(s) & 3.0 \\
\hline 325 & 18.8 & 153.0 & cone & & 2.0 \\
\hline 326 & 20.9 & 153.2 & pancake & crater(s) & 4.4 \\
\hline 327 & 18.7 & 153.3 & pancake & & 3.2 \\
\hline 328 & 19.5 & 153.4 & pancake & summit mound & 5.9 \\
\hline 329 & 18.3 & 153.4 & pancake & summit mound & 3.8 \\
\hline 330 & 19.0 & 153.4 & heap & & 1.6 \\
\hline 331 & 19.0 & 153.4 & heap & & 2.5 \\
\hline 332 & 19.0 & 153.4 & heap & & 1.6 \\
\hline 333 & 19.0 & 153.4 & heap & crater $(s)$ & 2.2 \\
\hline 334 & 18.7 & 153.4 & heap & summit mound & 3.7 \\
\hline 335 & 19.0 & 153.5 & heap & & 1.4 \\
\hline 336 & 19.0 & 153.5 & heap & & 1.4 \\
\hline 337 & {$[9.0$} & 153.6 & heap & & 2.6 \\
\hline
\end{tabular}


Appendix A (continued)

\begin{tabular}{|c|c|c|c|c|c|}
\hline ID & $\begin{array}{l}\text { Lat. } \\
\text { (N) }\end{array}$ & $\begin{array}{l}\text { Long. } \\
\text { (W) }\end{array}$ & Tуре & Secondary feature(s) & $\begin{array}{l}\text { Ave dia. } \\
(\mathrm{km})\end{array}$ \\
\hline 338 & 19.0 & 153.6 & heap & & 16.0 \\
\hline 339 & 20.7 & 153.7 & pancake & crater(s) & 4.6 \\
\hline 340 & 20.6 & 153.7 & pancake & & 5.8 \\
\hline 341 & 19.1 & 153.8 & heap & & 36.5 \\
\hline 342 & 19.2 & 154.0 & pancake & & 3.2 \\
\hline 343 & 17.1 & 154.1 & pancake & & 4.7 \\
\hline 344 & 19.4 & 154.2 & heap & & 18.2 \\
\hline 345 & 20.1 & 154.2 & cone & & 5.9 \\
\hline 346 & 16.8 & 154.3 & pancake & crater(s) & 3.0 \\
\hline 347 & $\mathrm{I} 6.8$ & 154.4 & pancake & & 2.4 \\
\hline 348 & 21.1 & 154.4 & heap & & 2.1 \\
\hline 349 & 20.2 & I 54.4 & pancake & & 2.8 \\
\hline 350 & 21.1 & 154.4 & pancake & & 2.0 \\
\hline $35 \mathrm{I}$ & 16.7 & 154.4 & heap & summit mound & 2.5 \\
\hline 352 & 16.8 & 154.5 & heap & & 2.1 \\
\hline 353 & 16.8 & $\mathrm{I} 54.5$ & heap & & 3.6 \\
\hline 354 & 16.9 & 154.5 & heap & & 2.9 \\
\hline 355 & 16.7 & I 54.5 & pancake & & 3.0 \\
\hline 356 & 16.9 & 154.5 & heap & & 2.4 \\
\hline 357 & 21.0 & 154.5 & pancake & & 3.0 \\
\hline 358 & 16.9 & 154.5 & heap & crater(s) & 2.3 \\
\hline 359 & 16.7 & 154.6 & pancake & & 2.4 \\
\hline 360 & 16.2 & 154.6 & pancake & & 5.0 \\
\hline 361 & 17.6 & 154.6 & heap & & 3.4 \\
\hline 362 & 17.6 & 154.7 & pancake & & 4.8 \\
\hline 363 & 18.6 & 154.7 & pancake & summit mound & 2.4 \\
\hline 364 & 17.6 & 154.7 & pancake & & 4.8 \\
\hline 365 & 16.1 & 154.7 & heap & & 5.4 \\
\hline 366 & {$[6.4$} & 155.4 & pancake & & 10.1 \\
\hline 367 & 16.3 & 155.5 & pancake & & 5.8 \\
\hline 368 & 16.7 & 156.0 & heap & & 3.2 \\
\hline 369 & 16.6 & I56.I & heap & summit mound & 3.2 \\
\hline 370 & 16.7 & 156.1 & heap & & 2.4 \\
\hline 371 & 15.8 & 156.1 & cone & & 2.3 \\
\hline 372 & 16.0 & 156.4 & pancake & & 1.6 \\
\hline 373 & I6.I & 156.6 & heap & & 13.9 \\
\hline 374 & I6.I & 156.6 & heap & & 9.4 \\
\hline 375 & 18.7 & 156.9 & heap & & 34.2 \\
\hline 376 (Jaggar) & {$[9.3$} & 156.9 & ridge mound? & & 27.4 \\
\hline 377 & 16.3 & 157.0 & heap & & 10.4 \\
\hline 378 & 16.3 & 157.1 & cone & & 2.4 \\
\hline 379 (Pensacola) & 18.3 & 157.2 & star & & 18.3 \\
\hline 380 & 15.7 & 157.2 & cone & & 1.4 \\
\hline 381 & 15.9 & 157.6 & pancake & & 2.0 \\
\hline 382 & 15.9 & 157.6 & cone & & 2.4 \\
\hline 383 & 17.4 & 157.8 & heap & summit mound & 2.4 \\
\hline 384 & 17.0 & 157.9 & pancake & & 3.6 \\
\hline 385 (Cross) & 18.7 & 158.1 & star? & & 25.3 \\
\hline 386 (Brigham) & 19.1 & 158.6 & ridge mound? & & 20.6 \\
\hline 387 (Bishop) & 18.8 & 159.0 & heap? & & 25.1 \\
\hline 388 & 19.8 & 159.2 & pancake & summit mound & 5.2 \\
\hline 389 & 19.8 & 159.3 & pancake & crater(s) & 2.6 \\
\hline 390 & 18.6 & 160.0 & pancake & & 4.2 \\
\hline
\end{tabular}




\section{References}

Abers, G.A., Parsons, B., Weissel, J.K., 1988. Seamount abundances and distributions in the southeast Pacific. Earth Planet. Sci. Lett. 87, 137-151.

Atwater, T., Severinghaus, J., 1988. Tectonic map of the north central Pacific Ocean. In: The Eastern Pacific Ocean and Hawaii, Vol. N of the Geology of North America. Geol. Soc. Am., Boulder, $\mathrm{CO}$

Barone, A.M., Ryan, W.B.F., 1990. Single plume model for asynchronous formation of the Lamont seamounts and adjacent East Pacific Rise terrains. J. Geophys. Res. 95, $10,801 \cdot 10,827$

Batiza, R., 1982. Abundances, distribution, and sizes of volcanoes in the Pacific Ocean and implications for the origin of non-hotspot volcanoes.. Earth Planet. Sci. Lett. 60, 195206.

Batiza, R., 1989. Seamounts and seamount chains of the Eastern Pacific. In: Winterer, E.L., Hussong, D.M., Decker, R.W. (Eds.), The Eastern Pacific Occan and Hawaii, Vol. N. of The Geology of North America. Geol. Soc. Am., Boulder, CO, pp. 289306.

Batiza, R., Vanko, D., 1983. Volcanic development of small oceanic central volcanoes on the flanks of the East Pacific Rise inferred from narrow-beam echo-sounder surveys. Mar. Geol. 54, 5390.

Batiza, R., Vanko, D., 1984. Petrology of young Pacific seamounts. J. Geophys. Res. 89, 11,235- I1,260.

Bemis, K.G., Smith, D. K., 1993. Production of small volcanoes in the Superswell region of the South Pacific. Earth Planet. Sci. Let1. 118, 251-262.

Cailleux, A., 1975. Frequence des monts sous-marins dans trois parties des océans pacifique et indien. Cah. Géogr. Qué. 19,553 .

Chase, T.E., Young, J.D., Degnan, C.H., Lucky, H.E.R., Riordan, J.A., Webber, L.D., 1992. Marine topography of offshore Hawaiian islands. In house U.S. Geol. Surv. Map Ser.

Clague, D.A., Dalrymple, G.B., 1989. The Hawaiian Emperor volcanic chain, Part 1: Geologic evolution. In: Decker, R.W., Wright, T.L., Stauffer P.H. (Eds.), Volcanism in Hawail, Vol. 1. U.S. Geol. Surv., Prof. Pap. 1350, 554 [also published as: Clague, D.A., Dalrymple, G.B., 1987. Tectonics, geochronology, and origin of the Hawaiian Emperor volcanic chain. In: Winterer, E.L., Hussong, D.M., Decker, R.W. (Eds.), The Eastern Pacific Ocean and Hawaii, Vol. N of The Geology of North America. Geol. Soc. Am., Boulder, CO, pp. 188 2171.

Clague, D.A., Holcomb, R.T., Sinton, J.M., Detrick, R.S., Torresan, M.E., 1990. Pliocene and Pleistocene alkalic flood basalts on the seafloor north of the Hawaiian Islands. Earth Planet. Sci. Lett. 98, 175191.

Edwards, M.H., Fornari, D.J., Malinverno, A., Ryan, W.B.F., 1991. The regional tectonic fabric of the East Pacific Risc from 1250N to 1510N. J. Geophys. Res. 96, 7995-8017.

Fornari, D.J., Campbell, J.F., 1987. Submarine topography around the Hawaiian Islands. In: Decker, R.W., Wright, T.L., Stauffer, P.H. (Eds.), Volcanism in Hawaii, Vol. 1. U.S Geol. Surv., Prof. Pap. 1350, 109-124.
Fornari, D.J, Ryan, W.B.F., Fox, P.J., 1984. The evolution of craters and calderas on young seamounts: Insights from Sea Marc I and Sea Beam sonar surveys of a small scamount group near the axis of the East Pacific Rise at $-10 \mathrm{~N}$. J. Geophys. Res. 89, 11,069-11,083.

Fornari, D.J., Batiza, R., Allen, J.F., 1987a. Irregularly shaped scamounts near the East Pacific Rise: Implications for seamount origin and rise axis processes. In: Keating. B.H., Fryer, B., Batiza, R., Boehlert, G.W. (Eds.), Seamounts, Islands, and Atolls. Am. Geophys. Union, Washington, DC, pp. 35-47.

Fornari, D.J., Batiza, R., Luckman, M.A., 1987b. Seamount abundances and distribution near the East Pacific Rise 0-24 $\mathrm{N}$ based on seabeam data. In: Keating, B.H., Fryer, B., Batiza, R., Boehlert, G.W. (Eds.), Seamounts, Islands, and Atolls. Am. Geophys. Union, Washington, DC, pp. 1321.

Gardner, J., 1992. The face of the U.S. seafloor. U.S. Geol. Surv., Public Iss. Energy Mar. Geol., 2 pp.

Geyer, R.A. (Ed.), 1992. CRC Handbook of Geophysical Exploration at Sea, Hard Minerals, 2nd ed. CRC Press, Boca Raton, FL, $86 \mathrm{pp}$.

Hess, P.C., 1989. Origins of Igneous Rocks. Harvard University Press, Cambridge, MA, $336 \mathrm{pp}$.

Hollister, C.D., Glenn, M.F., Lonsdale, P.F., 1978. Morphology of seamounts in the Western Pacific and Philippine Basin from multi-beam sonar data. Earth Planet. Sci. Lett. 4l, 405418

Hull, D.M., 1993. 1. Quaternary, Eocene, and Cretaceous radiolarians from the Hawaiian Arch, northern Equatorial Pacific Ocean. In: Dearmont, L.H., Marin, J.A. (Eds.), Proceedings of the Ocean Drilling Program, Scientific Results, Vol. 136. Ocean Drill. Prog., College Station, TX, pp. 3-25.

Jordan, T.H., Menard, H.W., Smith, D.K., 1983. Density and size distribution of seamounts in the Eastern Pacific inferred from wide-beam sounding data. J. Geophys. Res. 88, $10,508 \quad 10,518$.

Lonsdale, P.F., 1985. Nontransform offsets of the Pacific Cocos Plate boundary and their traces on the rise flank. Geol. Soc. Am. Bull. 96, 313327.

Macdonald, K.C., 1989. Tectonic and magmatic processes on the East Pacific Rise. In: Winterer, E.L., Hussong, D.M., Decker, R.W. (Eds.), The Eastern Pacific Ocean and Hawaii, Vol. N. of The Geology of North America. Geol. Soc. Am., Boulder, $\mathrm{CO}$, pp. $93 \mathrm{l} 10$.

Macdonald, K.C., Sempere, J.-C., Fox, P.J., 1984. East Pacific Rise from Siqueiros to Orozco fracture zones: Along-strike continuity of axial neovolcanic zones and structure and evolution of overlapping spreading centers. J. Geophys. Res. 89, 6049. 6069

Mammerickx, J., 1989. Large-scale undersea features of the Northeast Pacific. In: Winterer, E.L., Hussong, D.M., Decker, R.W. (Eds.), The Eastern Pacific Ocean and Hawaii, Vol. N of The Geology of North America. Geol, Soc. Am., Boulder, CO. pp. $5 \cdot 14$.

Menard, H.W., 1959. Geology of the Pacific seafloor. Experimentia $15,205-213$. 
Moore, J.G., 1987. Subsidence of the Hawaiian Ridge. In: Decker, R.W., Wright, T.L., Stauffer, P.H. (Eds.), Volcanism in Hawaii, Vol. 1, U.S. Geol. Surv., Prof. Pap. 1350, 85100.

Moore, J.G., Clague, D.A., Holcomb, R.T., Lipman, P.W., Normark, W.R., Torresan, M.E., 1989. Prodigious submarine landslides on the Hawailan Ridge. J. Geophys. Res. 94, $17,465 \quad 17,484$.

Moore, J.G., Normark, W.R., Holcomb, R.T., 1994. Giant Hawaiian landslides. Annu. Rev. Earth Planet. Sci. 22, 119- [44.

Phipps Morgan, J., Morgan, W.J., Price, E, 1995. Hotspot melting generates both hotspot volcanism and a hotspot swell? J. Geophys. Res. 100, 8045 8062 .

Pringle, M.S., 1992. Geochronology and petrology of the Musicians seamounts, and the search for hot spot volcanism in the Cretaceous Pacific. Ph.D. dissertation, University of Hawaii, Honolulu, HI, $235 \mathrm{pp}$.

Pringle, M.S., 1993. Age progressive volcanism in the Musicians seamounts: A test of the hot spot hypothesis for Late Cretaceous Pacific. In: The Mesozoic Pacific: Geology, Tectonics, and Volcanism. Am. Geophys. Union, Geophys. Monogr. 77, 187-215.

Pringle, M.S., Sinton, J.M., Staudigel, H., 1990. Petrology of the Musicians and S. Hawaiian seamounts: Anomalous nearridge seamount volcanism. Trans. Am. Gcophys. Union $71,1667$.

Scheirer, D.S., Macdonald, K.C., 1995. Near-axis seamounts on the flanks of the East Pacific Rise. J. Geophys. Res. 100 , $2239 \cdot 2259$.
Searle, R.C., 1983. Submarine central volcunoes on the Nazca Plate - High-resolution sonar observations. Mar. Geol. $53,77-102$.

Smith, D.K., 1988. Shape analysis of Pacific seamounts. Earth Planet. Sci. Lett. 90, 457466

Smith, D.K., 1991. Seamount abundances and size distributions, and their geographic variations. Rev. Aquat. Sci. 5, 197-210

Smith, D.K., Jordan, T.H., 1988. Seamount statistics in the Pacific Ocean. J. Geophys. Res. 93, $2899 \ldots 2918$.

Udistsev, G.B., Agapova, G.V., Larina, N.I., Marova, N.A., 1976. Seamounts of the Pacific Ocean - General features of relief of Pacific Ocean floor. In: Aoki, H., Lizuka, S. (Eds.), Volcanoes and Tectonosphere. Tokai University Press, Tokyo.

Vogt, P.R., Smoot, N.C., 1984. The Geisha guyots: Multibeam bathymetry and morphometric interpretation. J. Geophys. Res. 89, 11,085-11,107.

Wessel, P., 1993. A reeaximination of the flexural deformation beneath Hawaiian Islands. J. Geophys. Res. 98 $12,177-12,190$.

Wessel, P., Keating, B.H., 1993. Temporal variations of flexural deformation in Hawaii. J. Geophys. Res. 98, 2747-2756.

Winterer, E.L., 1989. Sediment thickness map of the Northeast Pacific. In: Winterer, E.L., Hussong, D.M., Decker, R.W. (Eds.), The Eastern Pacific Ocean and Hawaii, Vol. $N$ of The Geology of North America. Geol. Soc. Am., Boulder, CO, pp. 307-310. 


\section{=}


Advertising orders and enquiries may be sent to: Elsevier Science, Advertising Department, The Boulevard, Langford Lane, Kidlington, Oxford, OX5 1GB, UK, tel.: $(+44)(0) 1865843565$, fax: $(+44)(0) 1865843976$. In the USA and Canada: Weston Media Associates, attn. Dan Lipner, P.O. Box 1110, Greens Farms, CT 06436-1110, USA, tel.: (203) 2612500 , fax: (203) 2610101 . In Japan: Elsevier Science Japan, Marketing Services, 1-9-15 Higashi Azabu, Minato-Ku, Tokyo 106, tel.: $(+81) 355615033$, fax: $(+81) 355615047$.

\section{NOTE TO CONTRIBUTORS}

A detailed Guide for Authors is available upon request. Please pay attention to the following notes:

Language

The official language of the journal is English.

Preparation of the text

a) The manuscript should preferably be prepared on a word processor and printed with double spacing and wide margins and include an abstract of not more than 500 words. Also provide 4 to 6 keywords. These must be taken from the most recent edition of the AGI GeoRef Thesaurus and should be placed beneath the abstract.

b) Authors should use IUGS terminology. The use of S.I. units is also recommended.

c) The title page should include the name(s) of the author(s), their affiliations, fax and e-mail numbers. In case of more than one author, please indicate to whom the correspondence should be addressed.

References

a) References in the text consist of the surname of the author(s), followed by the year of publication in parentheses. All references cited in the text should be given in the reference list and vice versa.

b) The reference list should be in alphabetical order.

Tables

Tables should be compiled on separate sheets and should be numbered according to their sequence in the text. Tạbles can also be sent as glossy prints to avoid errors in typesetting

Illustrations

a) All illustrations should be numbered consecutively and referred to in the text.

b) Drawings should be lettered throughout, the size of the lettering being appropriate to that of the drawings, but taking into account the possible need for reduction in size. The page format of the journal should be considered in designing the drawings.

c) Photographs must be of good quality, printed on glossy paper.

d) Figure captions should be supplied on a separate sheet.

e) If contributors wish to have their original figures returned this should be requested in proof stage at the latest f) Colour figures can be accepted providing the reproduction costs are met by the author. Please consult the publisher
for further information.

Page proofs

One set of page proofs will be sent to the corresponding author, to be checked for typesetting/editing. The author is not expected to make changes or corrections that constitute departures from the article in its accepted form. Proofs should be returned within 3 days. To avoid postal delay, authors are requested to return corrections to the desk-editor, Mr. Bernard Westerop, by FAX (+31.20.4852459) or e-mail (b.westerop@elsevier.nl).

Reprints

Fifty reprints of each article are supplied free of charge. Additional reprints can be ordered on a reprint order form which will be sent to the corresponding author upon receipt of the accepted article by the publisher.

Submission of manuscripts

a) All manuscripts should be submitted in triplicate to the Editorial Office Marine Geology, P.O. Box 1930, 1000 BX Amsterdam. The Netherlands.

b) Illustrations should also be submitted in triplicate. One set should be in a form ready for reproduction: the other two may be of lower quality.

c) Authors are requested to submit the names, addresses and telephone, facsimile and e-mail numbers of four potential referees with their manuscripts.

d) Letter-type contributions should be submitted in triplicate to the Editorial Office Marine Geology, Letter Section, P.O. Box 1930, 1000 BX Amsterdam. The Netherlands. Contributions for this section should not exceed 8 printed pages and should be complete in themselves. No foldout illustrations can be accepted. The manuscripts received will be published ca. three months after acceptance. In order to achieve rapid publication, no proofs will be sent to the authors. Manuscripts should therefore be prepared with the greatest possible care.

e) The indication of a FAX and e-mail number on submission of the manuscript could assist in speeding communications. The FAX number for the Amsterdam office is: $+31-20-4852696$. f) Submission of an article is understood to imply that the article is original and unpublished and is not being considered
for publication elsewhere.

Submission of electronic text

Authors are requested to submit the final text on a $3.5^{\prime \prime}$ or $5.25^{\prime \prime}$ diskette. It is essential that the name and version of the word processing program, the type of computer on which the text was prepared, and the format of the text files are clearly indicated.

Authors are requested to ensure that the contents of the diskette correspond exactly to the contents of the hard copy manuscript. Discrepancies can lead to proofs of the wrong version being made. The word processed text should be in single column format.

If available, electronic files of the figures should also be included on a separate floppy disk.

Authors in Japan please note: Upon request, Elsevier Science Japan will provide authors with a list of people who can check and improve the English of their paper (before submission). Please contact our Tokyo office: Elsevier Science Japan, 1-9-15 Higashi Azabu, Minato-ku, Tokyo 106, tel. $(+81)-3-5561-5032$, fax $(+81)-3-5561-5045$. 


\title{
South Pacific Sedimentary Basins
}

\author{
Edited by P.F. Ballance
}

\section{Sedimentary Basins of the World Volume 2}

Sedimentary basins contain most of the extant record of the earth's history, and they provide us with most of our earth-sourced raw materials. Therefore their study is both scientifically and economically important. this book gives the first comprehensive coverage of sedimentary basins in the New Zealand region. Comprising 21 chapters by 32 authors, it dlscusses sedimentary basins ranging in age from Permian to Quaternary. The chapters are process- and topic-oriented.

Three distinct basin-forming periods are covered:

1) Permian through Jurassic

arc-related terranes;

2) Mid-Cretaceous through

Oligocene extensional basins;

3) Neogene convergent margin basins.

Resource scientists investigating sedimentary basins and all researchers working on basin-related toplcs will find this volume of interest.

Contents: Introduction. List of Contributors. PART A: Basins Related to Permian-to-Early Cretaceous Convergence on the Gondwana Margin.

1. Geology and Geochemistry of the Caples Terrane, Otago, New Zealand: Compositional

Variations near a Permo.

Triassic Arc Margin

(B.P. Roser et al.). 2. The

Murihiku Arc-Related Basin of

New Zealand (Triassic-

Jurassic) (P.F. Ballance,

J.D. Campbell). PART B:

Basins Related to

Cretaceous-to-Paleogene

Extension, 3. Cretaceous

Continental Rifts: New Zealand

Region (M.G. Laird).

4. Sedimentary Evolution of

the Bounty Trough: a

Cretaceous Rift Basin

Southwestern Pacific Ocean.

(L. Carter, R.M. Carter). 5. The Bounty Trough - Basement
Structure Influences on Sedimentary Basin Evolution (B. Davy). 6. The PaleoPacific, Post-Subduction, Passive Margin Thermal Relaxation Sequence (Late Cretaceous-Paleogene) of the Drifting New Zealand

Continent (P.F. Ballance). PART C: Basins Related to Neogene Convergence.

7. The Tempestuous 10 Million Year Life of a Double Arc and Intra-Arc Basin - New

Zealand's Northland Basin in the Early Miocene

(B.W. Hayward). 8. Volcano-

Tectonic Controls on

Sedimentation in the Taupo

Volcanic Zone, New Zealand

(R.C.M. Smith et al.). 9. The

Tonga Frontal-Arc Basin

(D.R. Tappin). 10. The New

Zealand Neogene Forearc

Basins (P.F. Ballance).

11. Southern Havre

Trough-Bay of Plenty (New

Zealand): Structure and

Seismic Stratigraphy of an

Active Back-Arc Basin

Complex (I.C. Wright).

12. Crustal Dynamics

Associated with the Formation

of Wanganui Basin. New

Zealand (T.A. Stern,

G.M. Quinlan, W.E. Holt).

13. The Emerging, Imbricate

Frontal Wedge of the

Hikurangi Margin (K.B. Lewis

J.R. Pettinga). 14. Cenozoic

Basins Adjacent to an Evolving

Transform Plate Boundary,

Southwest New Zealand

(R.J. Norris, I.M. Turnbull).

15. A Subsiding Platform

Adjacent to a Plate Boundary

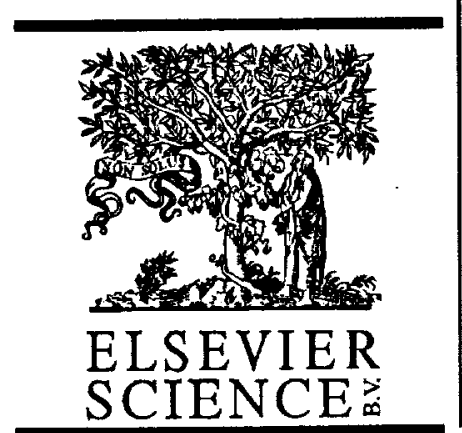

Transpression Zone: Neogene of Canterbury, New Zealand

(B.D. Field, G.H. Browne).

16. Regression-Related

Coal-Bearing Sequences in

the Neogene of New Zealand:

Relation to the Developing

Alpine Fault Transform

(P.J. Crosdale). 17. Hauraki

Rift: A Young, Active,

Intra-Continental Rift in a

Back-Arc Setting

(M.P. Hochstein,

P.F. Ballance).

PART D: Individual Basins

with Dual Histories:

Cretaceous-to-Paleogene

Extension Followed by

Neogene Convergence.

18. Cretaceous-Tertiary

Sedimentation and Implied

Tectonic Controls on the

Structural Evolution of

Taranaki Basin. New Zealand

(J.A. Palmer, P.B. Andrews).

19. The Chatham Rise, Now

Zealand (R.A. Wood,

R.H. Herzer). 20. The

Challenger Plateau

(R.A. Wood). 21. Depositional and Tectonic History of the

Great South Basin

(J.M. Beggs). PART E:

Summary. 22. A Distant View

of South Pacific Geology

(K.J. Hsü). References

Index. Subject Index.

1993436 pages

Dfl. 345.00 (US $\$ 197.25$ )

ISBN 0.444-88287-1

ELSEVIER SCIENCE B.V

P. O. Box 1930

1000 BX Amsterdam

The Netherlands

\section{P. O. Box 945}

Madison Square Station

New York, NY 10160-0757

The Dutch Guilder (Dfl.) prices quoted apply worldwide. US \$ prices quoted may be subject to exchange rate fluctuations. Customers in the European Community should add the appropriate VAT rate applicable in their country to the price. 